\title{
A model inter-comparison study to examine limiting factors in modelling Australian tropical savannas
}

\author{
Rhys Whitley ${ }^{1}$, Jason Beringer ${ }^{2}$, Lindsay B. Hutley ${ }^{3}$, Gab Abramowitz ${ }^{4}$, Martin G. De Kauwe ${ }^{1}$, Remko Duursma ${ }^{5}$, \\ Bradley Evans $^{6}$, Vanessa Haverd ${ }^{7}$, Longhui Li $^{8}$, Youngryel Ryu ${ }^{9}$, Benjamin Smith ${ }^{10}$, Ying-Ping Wang ${ }^{11}$, \\ Mathew Williams ${ }^{12}$, and Qiang Y $\mathbf{u}^{7}$ \\ ${ }^{1}$ Department of Biological Sciences, Macquarie University, North Ryde, NSW 2109, Australia \\ ${ }^{2}$ School of Earth and Environment, University of Western Australia, Crawley, WA 6009, Australia \\ ${ }^{3}$ School of Environment, Charles Darwin University, Casuarina, NT 0810, Australia \\ ${ }^{4}$ Climate Change Research Centre, University of New South Wales, Kensington, NSW 2033, Australia \\ ${ }^{5}$ Hawkesbury Institute for the Environment, University of Western Sydney, Penrith, New South Wales 2751, Australia \\ ${ }^{6}$ Faculty of Agriculture and Environment, University of Sydney, Eveleigh, NSW 2015, Australia \\ ${ }^{7}$ CSIRO Ocean and Atmosphere, Canberra 2601, Australia \\ ${ }^{8}$ School of Life Sciences, University of Technology Sydney, Ultimo, NSW 2007, Australia \\ ${ }^{9}$ Department of Landscape Architecture and Rural Systems Engineering, Seoul National University, Seoul, South Korea \\ ${ }^{10}$ Department of Physical Geography and Ecosystem Science, Lund University, Lund, Sweden \\ ${ }^{11}$ CSIRO Ocean and Atmosphere, Aspendale, Victoria 3195, Australia \\ ${ }^{12}$ School of GeoSciences, University of Edinburgh, Edinburgh, UK
}

Correspondence to: Rhys Whitley (rhys.whitley@mq.edu.au)

Received: 17 November 2015 - Published in Biogeosciences Discuss.: 2 December 2015

Revised: 16 May 2016 - Accepted: 17 May 2016 - Published: 3 June 2016

\begin{abstract}
The savanna ecosystem is one of the most dominant and complex terrestrial biomes, deriving from a distinct vegetative surface comprised of co-dominant tree and grass populations. While these two vegetation types co-exist functionally, demographically they are not static but are dynamically changing in response to environmental forces such as annual fire events and rainfall variability. Modelling savanna environments with the current generation of terrestrial biosphere models (TBMs) has presented many problems, particularly describing fire frequency and intensity, phenology, leaf biochemistry of $\mathrm{C}_{3}$ and $\mathrm{C}_{4}$ photosynthesis vegetation, and root-water uptake. In order to better understand why TBMs perform so poorly in savannas, we conducted a model inter-comparison of six TBMs and assessed their performance at simulating latent energy (LE) and gross primary productivity (GPP) for five savanna sites along a rainfall gradient in northern Australia. Performance in predicting LE and GPP was measured using an empirical benchmarking system, which ranks models by their ability to utilise meteorological driving information to predict the fluxes. On aver-
\end{abstract}

age, the TBMs performed as well as a multi-linear regression of the fluxes against solar radiation, temperature and vapour pressure deficit but were outperformed by a more complicated nonlinear response model that also included the leaf area index (LAI). This identified that the TBMs are not fully utilising their input information effectively in determining savanna LE and GPP and highlights that savanna dynamics cannot be calibrated into models and that there are problems in underlying model processes. We identified key weaknesses in a model's ability to simulate savanna fluxes and their seasonal variation, related to the representation of vegetation by the models and root-water uptake. We underline these weaknesses in terms of three critical areas for development. First, prescribed tree-rooting depths must be deep enough, enabling the extraction of deep soil-water stores to maintain photosynthesis and transpiration during the dry season. Second, models must treat grasses as a co-dominant interface for water and carbon exchange rather than a secondary one to trees. Third, models need a dynamic representation of LAI that encompasses the dynamic phenology 
of savanna vegetation and its response to rainfall interannual variability. We believe that this study is the first to assess how well TBMs simulate savanna ecosystems and that these results will be used to improve the representation of savannas ecosystems in future global climate model studies.

\section{Introduction}

Savanna ecosystems are a diverse and important biome that play a significant role in global land-surface processes (van der Werf et al., 2008). Globally, they occupy regions around the wet-dry tropical to sub-tropical equatorial zone, covering approximately 15 to $20 \%$ of the terrestrial surface and contribute $\sim 30 \%$ to global net primary production (Grace et al., 2006; Lehmann et al., 2014). Savannas are water-limited ecosystems where rainfall is often seasonal or monsoonal and have a spatial extent that can cover an area with annual rainfall in the range of 500 to $2000 \mathrm{~mm}$ (Bond, 2008; Kanniah et al., 2010; Sankaran et al., 2005). The variability in the amount and timing of annual rainfall, coupled with local topo-edaphic properties, and the frequency and intensity of seasonal fires strongly influence the structure and function of savanna vegetation (Beringer et al., 2007; Kanniah et al., 2010; Ma et al., 2013; Sankaran et al., 2005). Savannas are characterised by a multi-layer stratum of vegetation, where an open and discontinuous canopy overstorey is seasonally dominated by understorey grasses (Scholes and Archer, 1997). These tree and grass layers are distinctly and functionally different, fixing carbon using different photosynthetic pathways: $\mathrm{C}_{3}$ and $\mathrm{C}_{4}$ photosynthesis respectively (Bond, 2008; Scholes and Archer, 1997; R. J. Williams et al., 1996). The canopy overstorey can be either evergreen or deciduous (depending on the evolutionary history), while the grass understorey is annual: active only in the wet season and senescing at the end of this period (R. J. Williams et al., 1996). Consequently, water, carbon, and nutrient cycling in savannas is largely determined from the balance and co-existence of these two life forms (Lehmann et al., 2009; Sankaran et al., 2005).

Given the complex nature of savannas, modelling the land surface exchange and vegetation dynamics for this biome is challenging for terrestrial biosphere models (TBMs). Here we define TBMs to broadly encompass stand, land surface, and dynamic global vegetation models (Pitman, 2003). Most land surface schemes that feed into larger earth system models use simplistic representations of vegetation, and these will have difficulty describing the complex structure of savanna ecosystems. Such issues may be simplistic assumptions in relation to rooting depth and inadequate responses to drought (De Kauwe et al., 2015; Li et al., 2012); ignoring the multilayered nature of savannas and the differing structural (including radiation), functional (including different plant functional types), and phenological differences (Whitley et al.,
2011); and in some cases neglecting the $\mathrm{C}_{4}$ photosynthetic pathway entirely (Parton et al., 1983; Schymanski et al., 2007). It is therefore critical that TBMs meet the challenges that savanna dynamics present if water and carbon exchange are to be correctly simulated in response to global change.

Despite these issues, there have been significant advances in modelling savanna dynamics in recent years, and these have been focused on integrating important features specific to savanna ecosystems, namely frequent fire and tree-grass competitive interactions, which are processes that shape savanna structure and function (Haverd et al., 2016; Higgins and Scheiter, 2012; Scheiter and Higgins, 2007; Scheiter et al., 2014; Simioni et al., 2003). Nevertheless, little work has been undertaken to critically evaluate the performance and processes of TBMs when used to capture water and carbon cycling in savannas, most notably in West Africa (Simioni et al., 2000) and Australia (Schymanski et al., 2007, 2008, 2009; Whitley et al., 2011). Many global ecosystem models moreover use broad plant functional types (PFTs) with single parameter values to describe whole biomes (Pitman, 2003), making them unable to represent changing vegetation structure (tree : grass ratio) in the continuum of grassland to woodland savanna. Approaches have been developed that can account for savanna dynamics, such as using mixed tiles, whereby trees and grasses are simulated as separate surfaces that are then aggregated together (Kowalczyk et al., 2006). However, this approach fails to capture the competition between trees and grasses for light, water, and nutrient resources.

In this study, we take six TBMs of distinctly different conceptual frameworks and assess their ability to simulate savanna water and carbon exchange along the North Australian Tropical Transect (NATT), which is defined by a strong rainfall gradient. Australian tropical savannas can be considered largely intact compared to South American and African savannas and provide a "living laboratory" to understand the links between vegetation structure and function and how it responds to environmental change (Hutley et al., 2011). We challenge the models by evaluating them along the rainfall gradient, which extends over a broad biogeographical extent and strong interannual variability in climate (Koch et al., 1995). The aim of this study is to highlight critical processes that may be missing in current TBMs and are required to adequately simulate savanna ecosystems. Specifically, we examine whether a TBM's structural framework, such as the representation of the understorey grasses $\left(\mathrm{C}_{4}\right.$ photosynthesis), tree rooting depth, and description of phenology (prescribed vs. dynamic), can adequately replicate observed carbon and water fluxes. To achieve this we measure the performance of each TBM by comparing its predictions to a set of empirical benchmarks that describe a priori expected levels of model performance. We identify regions of low performance among sites and seasons to diagnose under what climate conditions reduced model performance occurs. We then infer what processes (present or missing) may be the cause for reduced per- 
formance when applied to savanna ecosystems. Our intention is that these results can be used to flag high priorities for future development by the terrestrial biosphere modelling community.

\section{Methodology}

\subsection{Observational data}

The NATT is a sub-continental rainfall gradient in the wetdry tropical climate zone of northern Australia, covering a distance of approximately $1000 \mathrm{~km}$ over a latitudinal range of -12 to $-23^{\circ} \mathrm{S}$ and a decline in mean annual precipitation (MAP) from 1700 to $300 \mathrm{~mm}$ (Hutley et al., 2011). It is one of three savanna transects established in the mid-1990s, forming part of the International Geosphere Biosphere Program (IGBP) along with the SAvannas in the Long Term (SALT) transect in West Africa and the Kalahari Transect in southern Africa (Koch et al., 1995). Soils range from sand-dominated red kandosols to black, cracking clay soils that are more extensive in the southern end of the NATT that are limiting to woody plant growth (Hutley et al., 2011; R. J. Williams et al., 1996). Kandosols are ancient and weathered, such that they have been leached of nutrients by the large monsoonal rainfall (McKenzie et al., 2004). Close to the northern coastline, vegetation is comprised primarily of evergreen Eucalyptus and Corymbia tree species that overly an understorey of $\mathrm{C}_{4}$ Sorghum and Heteropogon spp. grasses. Inland, tree biomass, leaf area index (LAI), and cover tends to decline and by $-18^{\circ} \mathrm{S}$ savanna vegetation transitions to less dense Acacia woodlands, shrublands, and grasslands that are dominated by Astrebla grass species (Hutley et al., 2011). Fires occur regularly in these environments, increasing in frequency with higher rainfall (MAP $>1000 \mathrm{~mm}$ ), and are fuelled by the accumulation of understorey $\mathrm{C}_{4}$ grasses that cure in the dry season (Beringer et al., 2015; Russell-Smith and Edwards, 2006).

The five flux tower sites along the NATT used in this study are outlined in Table 1, which describes stand soil and vegetation characteristics, as well as a summary of local meteorology (Hutley et al., 2011). These sites represent a sampling of savanna environments covering a wide range of MAP and a much smaller range of mean annual temperature (Fig. 1). At each site, an eddy covariance system was used to measure the ecosystem-atmosphere exchange of radiation, heat, water, and $\mathrm{CO}_{2}$. Quality assurance and control and corrections on the fluxes were carried out on the $30 \mathrm{~min}$ data set using the OzFlux QC/QA protocol (v2.8.5), developed by the OzFlux community under creative commons licensing (www.ozflux.org.au; see Eamus et al., 2013). Missing or rejected data were gap-filled using the DINGO (Dynamic INtegrated Gap filling and partitioning for Ozflux) system (see Moore et al., 2016). Gross primary productivity (GPP) was not observed but determined from the differ- ence between measured net ecosystem exchange (NEE) and modelled ecosystem respiration (Re). Values of Re were determined by assuming nocturnal NEE equals Re under the conditions for sufficient turbulent transport. Values that meet these requirements are then used to make daytime predictions of Re, using an artificial neural network (ANN), with soil moisture and temperature, air temperature, and the normalised difference vegetation index used as predictors. Additionally, the effect of fire on the water and carbon fluxes are quantified and incorporated into the data sets accounting for the nonlinear response in productivity (becoming a carbon source) during the post-fire recovery period (Beringer et al., 2007). Because the TBMs used here do not attempt to simulate stochastic fire events (and other disturbance regimes), these post-fire recovery periods were removed when determining the benchmarks and model performance as described below.

Finally, we use the definitions for water and carbon exchange as outlined by Chapin et al. (2006), whereby the subdaily rate of GPP is expressed in $\mu \mathrm{mol} \mathrm{m}{ }^{-2} \mathrm{~s}^{-1}$ and uses a negative sign (-) to denote the removal of $\mathrm{CO}_{2}$ from the atmosphere. Similarly, latent energy (LE) is expressed in terms of energy as $\mathrm{W} \mathrm{m}^{-2}$ and uses a positive sign to denote the addition of $\mathrm{H}_{2} \mathrm{O}$ to the atmosphere.

\subsection{Terrestrial biosphere models}

The six TBMs used in this study cover a wide spectrum of characteristics of operation, scale and function, and include differences in operational time step (30 min vs. daily), scope of simulated processes (soil hydrology, static or dynamic vegetation, multi-layer or big leaf description of the canopy), and intended operational use (coupled to earth system models, offline prediction, driven by remote sensing products). These characteristics along with what we define as a model "functional class" are given in Table 2 and are defined as follows. Stand models (SMs) give detailed multi-layer descriptions of canopy and soil processes for a particular point, operating at a sub-daily time step (Soil-Plant-Atmosphere model (SPA) and MAESPA). Land-surface models operate at the same temporal resolution as SMs, but they adopt a simpler representation of canopy processes, allowing them to be applied spatially (Community Atmosphere Biosphere Land Exchange model (CABLE) and BIOS2, a modified version of CABLE). Dynamic global vegetation models (DGVMs) simulate water and carbon much like the other models, but they simulate dynamic rather than static vegetation that changes in response to climate and disturbance (Lund-Potsdam-Jena General Ecosystem Simulator, LPJGUESS). Lastly, remote sensing models are driven by remotely sensed atmospheric products and infer water stress of vegetation through changes in fractional cover rather than detailed soil hydrological processes (Breathing Earth System Simulator, BESS). Some of the TBMs share similar structural frameworks in parts: for example, both SPA and MAESPA use similar belowground 
(a)

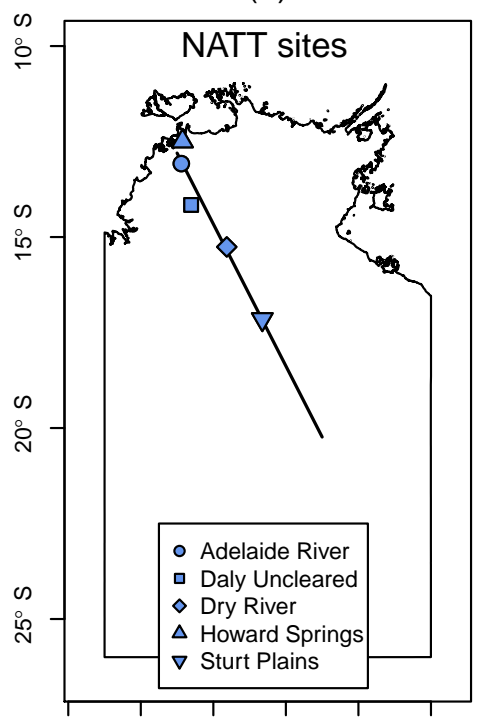

$128^{\circ} \mathrm{E} 130^{\circ} \mathrm{E} 132^{\circ} \mathrm{E} 134^{\circ} \mathrm{E} 136^{\circ} \mathrm{E} 138^{\circ} \mathrm{E}$ (b)

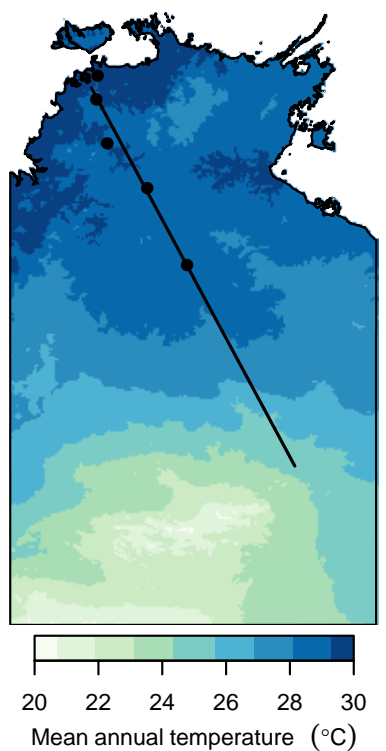

(c)

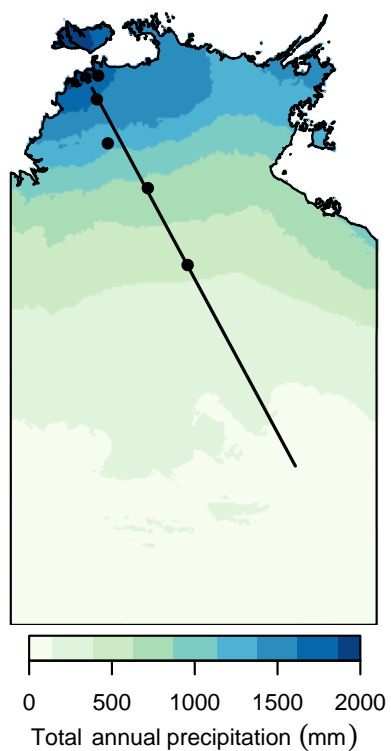

Figure 1. The Northern Territory of Australia and the North Australian Tropical Transect (NATT) showing (a) the flux site locations with an accompanying 30-year (1970 to 2000) expression of the average meteorological conditions for (b) mean annual temperature and (c) total annual precipitation derived from ANUCLIM v6.1 climate surfaces (Hutchinson and Xu, 2010).

soil hydrology and root-water uptake schemes, while BIOS2 is a fine spatial resolution $\left(0.05^{\circ}\right)$ offline modelling environment for Australia, in which predictions of CABLE (with alternate parameterisations of drought response and soil hydrology) are constrained by multiple observation types (see Haverd et al., 2013). Although these similarities reduce the number of truly functionally independent models used in the experiment, the presence of such overlap can be useful in identifying whether particular frameworks are the cause for model success or failure.

\subsection{Experimental protocol}

All TBMs were parameterised for each of the five savanna sites using standardised information on vegetation and soil profile characteristics (Table 1). For TBMs that required them, parameter values pertaining to leaf biochemistry, such as maximum Rubisco activity ( $V_{\mathrm{cmax}}$ ) and leaf nitrogen content per leaf area $\left(\mathrm{N}_{\text {area }}\right)$, were assigned from Cernusak et al. (2011), who undertook a physiological measurement campaign during the SPECIAL program (Beringer et al., 2011). Parameters relating to soil sand and clay content were taken from the Australian Soil Classification (Isbell, 2002), while root profile information was sourced from Chen et al. (2003) and Eamus et al. (2002). Each TBM was set up to describe a $\mathrm{C}_{3}$ evergreen overstorey with an underlying $\mathrm{C}_{4}$ grass understorey and conforms well with the characteristics of savannas in northern Australia (Bowman and Prior, 2005). All TBMs (excluding LPJGUESS) prescribed LAI as an input in order to characterise the phenology of vegetation at each site. In these cases LAI was determined from MODIS-derived approximations that were well matched to ground-based estimations of LAI at the SPECIAL sites (Sea et al., 2011). The fraction of $\mathrm{C}_{3}$ to $\mathrm{C}_{4}$ vegetation was handled differently by each model and was determined for each as follows. For MAESPA and SPA, the models allowed for time-varying tree and grass fractions to be assigned as direct inputs, and these time-varying fractions were determined using the method of Donohue et al. (2009). BIOS2 similarly used the same method to extract time-varying fractions, while CABLE used a static fraction that did not change. The BESS model derived the $\mathrm{C}_{3}: \mathrm{C}_{4}$ fraction from the $\mathrm{C}_{3}$ and $\mathrm{C}_{4}$ distribution map of Still et al. (2003), while for LPJGUESS this fraction is a prognostic determination resulting from the competition between trees and grasses (see Smith et al., 2001). Model simulations were driven using observations of solar radiation, air temperature, relative humidity (or vapour pressure deficit, VPD), rainfall, atmospheric $\mathrm{CO}_{2}$ concentration, and LAI (if prescribed), and they included a spin-up period of 5 years to allow internal states, such as the soil-water balance and soil temperature to reach equilibrium. The exception to the above was the BIOS2 model, which was run using gridded meteorological inputs and had its model parameters optimised through a model-data fusion process (see Haverd et al., 2013).

Simulations for each savanna site covered a period of 2 to 10 years, depending on the availability of data from each flux site (Table 1), and results were standardised to the ALMA (Assistance for Land-surface Modelling Activities) convention. Model predictions of LE and GPP were 
Table 1. Summarised data set information for each of the five savanna sites used in this study. This includes site descriptions pertaining to local meteorology, vegetation, and belowground soil characteristics. Where data were not available, the abbreviation n.a. is used. Definitions for the species genus mentioned in the table are as follows: Eucalyptus (Eu.),Erythrophleum (Er.), Terminalia (Te.), Corymbia (Co.), Planchonia (Pl.), Buchanania (Bu.), Themda (Th.), Hetropogan (He.), and Chrysopogon (Ch.). Eddy covariance data sets relating to each of the five sites here can be download from www.ozflux.org.au.

\begin{tabular}{|c|c|c|c|c|c|c|}
\hline & & Howard Springs $^{\mathrm{a}}$ & Adelaide River ${ }^{\mathrm{b}}$ & Daly Uncleared ${ }^{\mathrm{c}}$ & Dry River ${ }^{d}$ & Sturt Plains ${ }^{\mathrm{e}}$ \\
\hline & Years (inclusive) & 2001-2012 & $2007-2009$ & $2008-2012$ & $2008-2012$ & $2008-2012$ \\
\hline & \multirow[t]{2}{*}{ Co-ordinates } & $12^{\circ} 29^{\prime} 39.12^{\prime \prime} \mathrm{S}$ & $13^{\circ} 04^{\prime} 36.84^{\prime \prime} \mathrm{S}$ & $14^{\circ} 09^{\prime} 33.12^{\prime \prime} \mathrm{S}$ & $15^{\circ} 15^{\prime} 31.62^{\prime \prime} \mathrm{S}$ & $17^{\circ} 09^{\prime} 02.76^{\prime \prime} \mathrm{S}$ \\
\hline & & $131^{\circ} 09^{\prime} 09^{\prime \prime} \mathrm{E}$ & $131^{\circ} 07^{\prime} 04.08^{\prime \prime} \mathrm{E}$ & $131^{\circ} 23^{\prime} 17.16^{\prime \prime} \mathrm{E}$ & $132^{\circ} 22^{\prime} 14.04^{\prime \prime} \mathrm{E}$ & $133^{\circ} 21^{\prime} 01.14^{\prime \prime} \mathrm{E}$ \\
\hline & Elevation (m) & 64 & 90 & 110 & 175 & 250 \\
\hline \multicolumn{7}{|c|}{ Meteorology ${ }^{f}$} \\
\hline & Annual rainfall (mm) & 1714 & 1460 & 1170 & 850 & 535 \\
\hline & Min/max daily temperature $\left({ }^{\circ} \mathrm{C}\right)$ & $22.0 / 33.0$ & $21.8 / 35.3$ & $20.8 / 35.0$ & $20.0 / 34.8$ & $19.0 / 34.2$ \\
\hline & $\mathrm{Min} / \mathrm{max}$ absolute humidity $\left(\mathrm{g} \mathrm{m}^{-3}\right)$ & $11.0 / 18.5$ & $8.9 / 17.7$ & $8.6 / 15.1$ & $7.8 / 12.3$ & $6.1 / 9.0$ \\
\hline & $\operatorname{Min} /$ max soil moisture $\left(\mathrm{m}^{3} \mathrm{~m}^{-3}\right)$ & $0.06 / 0.1$ & $0.09 / 0.14$ & $0.03 / 0.06$ & $0.03 / 0.05$ & $0.04 / 0.1$ \\
\hline & Soil temperature $\left({ }^{\circ} \mathrm{C}\right)$ & 32.7 & 35.7 & 32.8 & n.a. & 30.2 \\
\hline & Solar radiation $\left(\mathrm{W} \mathrm{m}^{-2}\right)$ & 256.5 & 258.1 & 270.6 & 266.5 & 269.7 \\
\hline & Bowen ratio & 1.7 & 3.1 & 3.2 & 4.6 & 15.8 \\
\hline \multicolumn{7}{|c|}{ Vegetation $^{\mathrm{f}}$} \\
\hline & \multirow[t]{3}{*}{ Overstorey species } & Eu. Miniata & Eu. tectifica & Te. grandiflora & Eu. tetrodonta & \multirow[t]{4}{*}{ n.a. } \\
\hline & & Eu. tetrodonta & Pl. careya & Eu. tetrodonta & Co. terminalis & \\
\hline & & Er. chlorostachys & Co. latifolia & Co. latifolia & Eu. dichromophloia & \\
\hline & \multirow[t]{2}{*}{ Understorey species } & Sorghum spp. & Sorghum spp. & Sorghum spp. & Sorghum intrans & \\
\hline & & He. triticeus & Ch. fallax & He. triticeus & $\begin{array}{l}\text { Th. Tiandra } \\
\text { Ch. fallax }\end{array}$ & Astrabla spp. \\
\hline & Basal area $\left(\mathrm{m}^{2} \mathrm{ha}^{-1}\right)$ & 9.7 & 5.1 & 8.3 & 5.4 & n.a. \\
\hline & Canopy height (m) & 18.9 & 12.5 & 16.4 & 12.3 & 0.2 \\
\hline & $\operatorname{LAI}\left(\mathrm{m}^{2} \mathrm{~m}^{-2}\right)$ & $1.04 \pm 0.07$ & $0.68 \pm 0.07$ & $0.80 \pm 0.12$ & $0.58 \pm 0.11$ & $0.39 \pm 0.11$ \\
\hline & Total leaf nitrogen $\left(\mathrm{g} \mathrm{m}^{-3}\right)$ & $1.42 \pm 0.20$ & $1.27 \pm 0.18$ & $1.35 \pm 0.19$ & $1.97 \pm 0.15$ & $2.37 \pm 0.17$ \\
\hline \multicolumn{7}{|c|}{ Soilg $^{\mathrm{g}}$} \\
\hline & Type & Red kandosol & Yellow hydrosol & Red kandosol & Red kandosol & Grey vertosol \\
\hline \multirow[t]{7}{*}{ A horizon } & Texture & Sandy loam & Sandy loam & Loam & Clay & Loam \\
\hline & Clay PSD (\%) & 15 & 20 & 20 & 50 & 20 \\
\hline & Sand PSD (\%) & 60 & 50 & 40 & 25 & 40 \\
\hline & Thickness (m) & 0.30 & 0.30 & 0.20 & 0.15 & 0.20 \\
\hline & Bulk density $\left(\mathrm{Mg} \mathrm{m}^{-3}\right)$ & 1.29 & 1.60 & 1.39 & 1.20 & 1.39 \\
\hline & Hydraulic conductivity $\left(\mathrm{mm} \mathrm{h}^{-1}\right)$ & 9 & 7 & 9 & 3 & 9 \\
\hline & Field capacity $\left(\mathrm{mm} \mathrm{m}^{-1}\right)$ & 156 & 132 & 147 & 140 & 147 \\
\hline \multirow[t]{7}{*}{ B horizon } & Texture & Clay loam & Clay & Clay loam & Clay & Clay loam \\
\hline & Clay PSD (\%) & 40 & 55 & 35 & 55 & 35 \\
\hline & Sand PSD (\%) & 30 & 20 & 30 & 20 & 30 \\
\hline & Thickness (m) & 1.20 & 0.60 & 0.69 & 1.29 & 0.69 \\
\hline & Bulk density $\left(\mathrm{Mg} \mathrm{m}^{-3}\right)$ & 1.39 & 1.70 & 1.39 & 1.39 & 1.39 \\
\hline & Hydraulic conductivity $\left(\mathrm{mm} \mathrm{h}^{-1}\right)$ & 8 & 5 & 7 & 2 & 7 \\
\hline & Field capacity $\left(\mathrm{mm} \mathrm{m}^{-1}\right)$ & 146 & 31 & 146 & 107 & 146 \\
\hline
\end{tabular}

Hdl references are given by order of column Jason Beringer (2013); ${ }^{\mathrm{a}}$ hdl: $102.100 .100 / 14228,{ }^{\mathrm{b}}$ hdl: $102.100 .100 / 14239,{ }^{\mathrm{c}}$ hdl: $102.100 .100 / 14229,{ }^{\mathrm{d}}$ hdl: $102.100 .100 / 14234,{ }^{\mathrm{e}}$ hdl: $102.100 .100 / 14230$. Site meteorology is given as 30-year averages with values taken from ${ }^{\mathrm{f}}$ Hutley et al. (2011). Soil descriptions are taken from the Digital Atlas of Australian Soils (www.asris.csiro.au); ${ }^{\mathrm{g}}$ Isbell (2002).

evaluated against local observations at each site from the eddy covariance data sets and benchmarked following the methodology proposed by the Protocol for the Analysis of Land-surface models (PALS) and the PALS Land SUrface Model Benchmarking Evaluation PRoject (PLUMBER) (Abramowitz, 2012; Best et al., 2015) as described below.

\subsection{Empirical benchmarking}

The paradigm for model assessment outlined by PALS (Abramowitz, 2012) suggests that model assessment is more meaningful when a priori expectations of performance in any given metric can be defined. Such benchmarks can be created using simple empirical models, built on statistical relationships between the fluxes and drivers, and establish the de- 
Table 2. Summary table of the ecosystem models used in the experiment, highlighting differences and similarities in model structure and shared processes. Information is broken down into how each model describes aboveground canopy and belowground soil processes.

\begin{tabular}{|c|c|c|c|c|c|c|}
\hline Model name & SPA & MAESPA & CABLE & BIOS2 & BESS & LPJGUESS \\
\hline Model definition & Soil-Plant-Atmosphere model & MAESTRA-SPA & $\begin{array}{l}\text { Community Atmosphere } \\
\text { Biosphere } \\
\text { Land-surface Exchange } \\
\text { Model }\end{array}$ & $\begin{array}{l}\text { Modified CABLE (CABLE + SLI } \\
\text { + CASA-CNP) }\end{array}$ & $\begin{array}{l}\text { Breathing Earth System Simu- } \\
\text { lator }\end{array}$ & $\begin{array}{l}\text { Lund-Potsdam-Jena General } \\
\text { Ecosystem Simulator }\end{array}$ \\
\hline Version & 1.0 & 1.0 & 2.0 & 2.0 & 1.0 & 2.1 \\
\hline Reference & M. Williams et al. (1996) & Duursma and Medlyn (2012) & $\begin{array}{l}\text { Kowalyzck et al. (2006), } \\
\text { Wang et al. (2011) }\end{array}$ & Haverd et al. (2013) & Ryu et al. $(2011,2012)$ & Smith et al. (2001) \\
\hline Temporal resolution & $30 \min$ & $30 \mathrm{~min}$ & $30 \mathrm{~min}$ & $\begin{array}{l}\text { Daily ( } 30 \mathrm{~min} \text { time steps are gener- } \\
\text { ated from daily time series) }\end{array}$ & $\begin{array}{l}\text { Snapshot with MODIS over- } \\
\text { pass, then up-scaled to a daily } \\
\text { and } 8 \text {-day time series }\end{array}$ & Daily \\
\hline Spatial resolution & Point & Point & $0.05^{\circ}(5 \mathrm{~km})$ & $0.05^{\circ}(5 \mathrm{~km})$ & $0.05^{\circ}(5 \mathrm{~km})$ & Patch (c. 0.1 ha) \\
\hline Functional class & Stand model & Individual plant or stand model & Land-surface model & Land-surface model & Remote sensing model & Dynamic global vegetation model \\
\hline \multicolumn{7}{|c|}{ Canopy description } \\
\hline $\mathrm{C}_{3}$ assimilation & Farquhar et al. (1980) & Farquhar et al. (1980) & Farquhar et al. (1980) & Farquhar et al. (1980) & Farquhar et al. (1980) & Collatz et al. (1991) \\
\hline $\mathrm{C}_{4}$ assimilation & Collatz et al. (1992) & Collatz et al. (1992) & Collatz et al. (1992) & Collatz et al. (1992) & Collatz et al. (1992) & Collatz et al. (1992) \\
\hline Stomatal conductance & M. Williams et al. (1996) & Medlyn et al. (2011) & Leuning (1995) & Leuning (1995) & Ball et al. (1987) & Haxeltine and Prentice (1996) \\
\hline Transpiration & $\begin{array}{l}\text { Penman-Monteith calculated at leaf } \\
\text { scale accounting for } g b \text { and limita- } \\
\text { tion of soil-water } r \text { ply via } \Psi_{\text {i }}\end{array}$ & $\begin{array}{l}\text { Penman-Monteith } \\
\text { calculated at the leaf scale }\end{array}$ & Penman-Monteith & Penman-Monteith & Penman-Monteith & Haxeltine and Prentice (1996) \\
\hline Boundary layer resistance & $\begin{array}{l}f \text { (wind speed, leaf width, air tem- } \\
\text { perature) }\end{array}$ & $\begin{array}{l}f \text { (wind speed, leaf width, air temperature } \\
\text { and atmospheric pressure) }\end{array}$ & $\begin{array}{l}f \text { (wind speed, leaf width, air } \\
\text { temperature }\end{array}$ & $\begin{array}{l}f \text { (wind speed, leaf width, air tem- } \\
\text { perature }\end{array}$ & Not modelled & Huntingford and Monteith (1998) \\
\hline Aerodynamic resistance & f(wind speed, canopy height) & $\begin{array}{l}\text { Not calculated unless transpiration is cal- } \\
\text { culated at the canopy scale, in which case } \\
g_{b} \text { above is not calculated }\end{array}$ & f(wind speed, canopy height) & $f$ (wind speed, canopy height) & $f$ (wind speed, canopy height) & Huntingford and Monteith (1998) \\
\hline Leaf area index & Prescribed (MODIS) & Prescribed (MODIS) & Prescribed (MODIS) & Prescribed (MODIS) & Prescribed (MODIS) & $\begin{array}{l}\text { Prognostic } \\
\text { (C allocation) }\end{array}$ \\
\hline Canopy structure & $\begin{array}{l}\text { Canopy + understorey } \\
\text { divided into } 10 \text { layers }\end{array}$ & $\begin{array}{l}\text { Individual plant crowns, } \\
\text { spatially explicit locations and uniform } \\
\text { understorey }\end{array}$ & $\begin{array}{l}\text { Two (tree/grass) big leaf (sun- } \\
\text { lit/shaded) }\end{array}$ & $\begin{array}{l}\text { Two (tree/grass) big leaf (sun- } \\
\text { lit/shaded) }\end{array}$ & $\begin{array}{l}\text { Two (tree/grass) big leaf (sun- } \\
\text { lit/shaded) }\end{array}$ & $\begin{array}{l}5 \text {-year age/size cohorts for trees, } \\
\text { single-layer grass understorey }\end{array}$ \\
\hline $\mathrm{C}_{3}: \mathrm{C}_{4}$ fraction & $\begin{array}{l}\text { Dynamic ratio variable with time; } \\
\text { compete for water and light }\end{array}$ & $\begin{array}{l}\text { Dynamic ratio variable with time; com- } \\
\text { pete for water and light }\end{array}$ & $\begin{array}{l}\text { Simulated as independent lay- } \\
\text { ers }\end{array}$ & $\begin{array}{l}\text { Dynamic ratio variable with time; } \\
\text { compete for water not light }\end{array}$ & $\begin{array}{l}\text { Still et al. (2003) } \\
\text { Ratio changes } 70: 30 \text { to 10:90 } \\
\text { down transect }\end{array}$ & $\begin{array}{l}\text { Prognostic, determined as the out- } \\
\text { come of the competition with trees }\end{array}$ \\
\hline Canopy interception & Yes & Yes & Yes & Yes & No & Yes \\
\hline Simulates growth & No & No & No & No & No & Yes \\
\hline \multicolumn{7}{|c|}{ Soil profile description } \\
\hline Soil profile structure & $\begin{array}{l}\text { Profile divided into } n \\
\text { layers (prescribed }-20 \text { in this case) }\end{array}$ & $\begin{array}{l}\text { Profile divided into } n \\
\text { layers (prescribed }-20 \text { in this case) }\end{array}$ & Profile divided into 6 layers & $\begin{array}{l}\text { Profile divided into } 12 \text { layers (ad- } \\
\text { justable) }\end{array}$ & Not modelled & $\begin{array}{l}\text { Two layers }(0-0.5,0.5-2 \mathrm{~m}) \text { with } \\
10 \mathrm{~cm} \text { evaporation sub-layer }\end{array}$ \\
\hline Soil hydraulic properties & $\begin{array}{l}\text { Function of sand and clay particle } \\
\text { size distributions }\end{array}$ & $\begin{array}{l}\text { Function of sand and clay particle size } \\
\text { distributions }\end{array}$ & Prescribed & $\begin{array}{l}\text { Australian Soils Resource Informa- } \\
\text { tion System (ASRIS) }\end{array}$ & Not modelled & Sitch et al. (2003) \\
\hline Soil depth & $6.5 \mathrm{~m}$ & $5.0 \mathrm{~m}$ & $4.5 \mathrm{~m}$ & $10.0 \mathrm{~m}$ & Not modelled & $2 \mathrm{~m}$ \\
\hline Root depth & $6.5 \mathrm{~m}$ & $5.0 \mathrm{~m}$ & $4.5 \mathrm{~m}$ & $0.5 \mathrm{~m}$ (grasses), $5.0 \mathrm{~m}$ (trees) & Not modelled & $2 \mathrm{~m}$ \\
\hline Root distribution & $\begin{array}{l}\text { Prescribed; exponential decay as a } \\
\text { function of surface biomass and the } \\
\text { total root biomass of the column }\end{array}$ & $\begin{array}{l}\text { Prescribed; exponential decay as a func- } \\
\text { tion of surface biomass and the total root } \\
\text { biomass of the column }\end{array}$ & Prescribed; exponential decay & Prescribed; exponential decay & Not modelled & $\begin{array}{l}\text { PFT-specific; trees have deeper } \\
\text { roots on average }\end{array}$ \\
\hline Soil-water stress modifier & $\begin{array}{l}E_{t} \text { via } g_{s} \text { is increased to meet atmo- } \\
\text { spheric demand while } \Psi_{l} \text { remains } \\
\text { above a critical threshold }\end{array}$ & $\begin{array}{l}\text { Maximum transpiration rate calculated } \\
\text { from hydraulic conductance (soil-to-leaf) } \\
\text { sets limit on actual transpiration } \\
\text { or uses the Tuzet et al. (2003) model of } \\
\text { stomatal conductance }\end{array}$ & Supply/demand & $\begin{array}{l}g_{s} \text { scaled by a soil moisture limita- } \\
\text { tion function related to extractable } \\
\text { water accessible by roots }\end{array}$ & $\begin{array}{l}\text { Assumes LAI and seasonal } \\
\text { variation of } V_{\text {cmax rax reflect soil- }} \\
\text { water stress }\end{array}$ & Supply/demand \\
\hline Hydraulic pathway resistance & $R_{\text {soil }}+R_{\text {plant }}$ & $R_{\text {soil }}+R_{\text {plant }}$ & Not modelled & Not modelled & Not modelled & $\begin{array}{l}\text { Not explicit, min(supply, demand) } \\
\text { determines sap flow }\end{array}$ \\
\hline
\end{tabular}

gree to which models utilise the information available in their driving data about the fluxes they aim to predict. Additionally, these empirical models are simple in the sense that they are purely instantaneous response to time-varying meteorological forcing and contain no internal states or expression of ecophysiological processes. This is in comparison to TBMs that are complex, having some $20+$ soil and vegetation parameters, internal states, partitioning of light, as well as soil and vegetation, carbon, and nitrogen pools (Abramowitz et al., 2008).

We created a set of three empirical models of increasing complexity following the procedure of Abramowitz (2012), which we compared with the TBMs. The first benchmark (emp1) is simply a linear relationship between a turbulent flux (LE or GPP) and downward short-wave radiation $\left(R_{\mathrm{S}}\right)$. The second benchmark (emp2) is slightly more complex, and is a multi-linear regression between a flux and $R_{\mathrm{s}}$, air temperature $\left(T_{\mathrm{a}}\right)$, and VPD. Finally, the third benchmark (emp3) is the most complex and is a nonlinear regression of the fluxes against $R_{\mathrm{s}}, T_{\mathrm{a}}, \mathrm{VPD}$, and LAI, determined from an ANN. This benchmark is constructed using a self-organising linear output map that clusters the four covariates into $10^{2}$ distinct nodes and performs a multi-linear regression between the fluxes and the four covariates at each node, resulting in a nonlinear (piece-wise linear) response to the meteorological forcing data (Abramowitz et al., 2008; Hsu, 2002). In a departure from Abramowitz (2012), we include LAI as an additional covariate, as the seasonal variance of savanna water and carbon exchange is strongly coupled to the phenology of the grasses and to the deciduous and semi-deciduous woody species (Moore et al., 2016). The seasonal behaviour of the empirical benchmark drivers along the NATT can be referred to in the Supplement. Empirical benchmarks are created for each of the five flux sites using non gap-filled data and are parameterised out of sample, such that they use data from all sites except the one in question. For example, the Howard Springs empirical benchmark models would use information from Adelaide River, Daly Uncleared, Dry River, and Sturt Plains to establish their parameter values but would exclude Howard Springs itself. Constructing the benchmark out of sample results in what is effectively a generalised response to an independent data set. Once the empirical models were calibrated for each site, benchmarks were then created for both fluxes using the same meteorological forcing used to run the TBMs. 
(a) Howard Springs

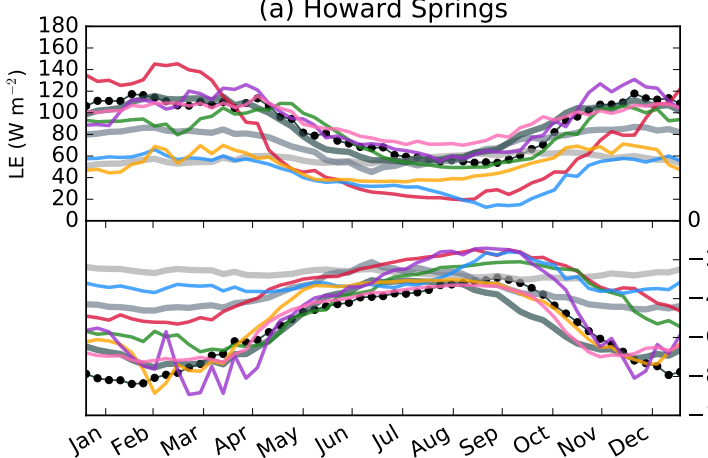

(c) Daly Uncleared

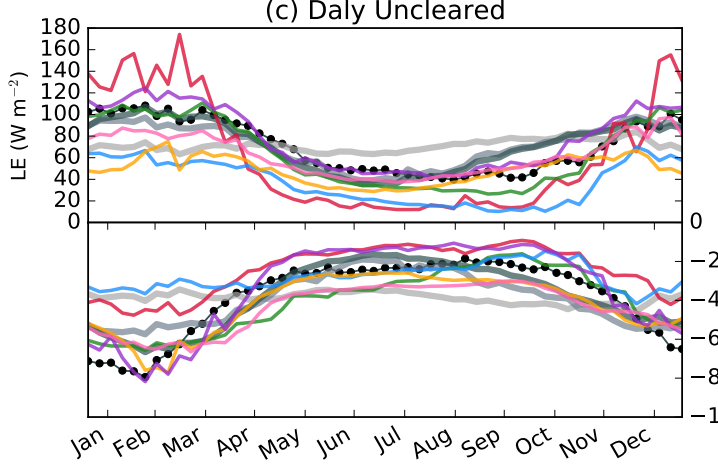

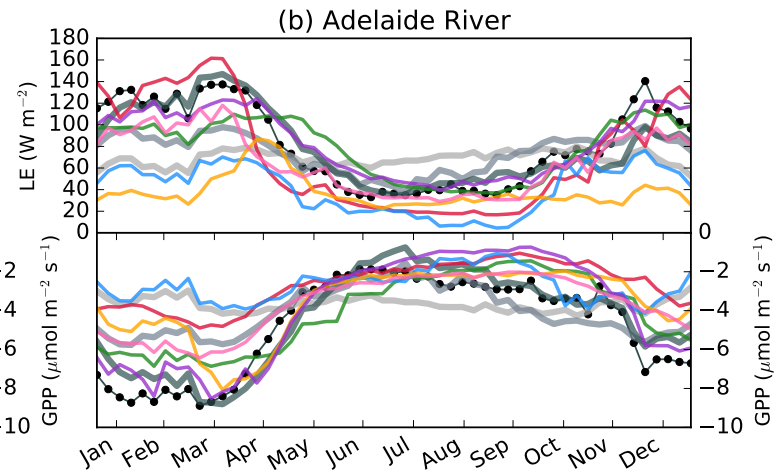

(d) Dry River

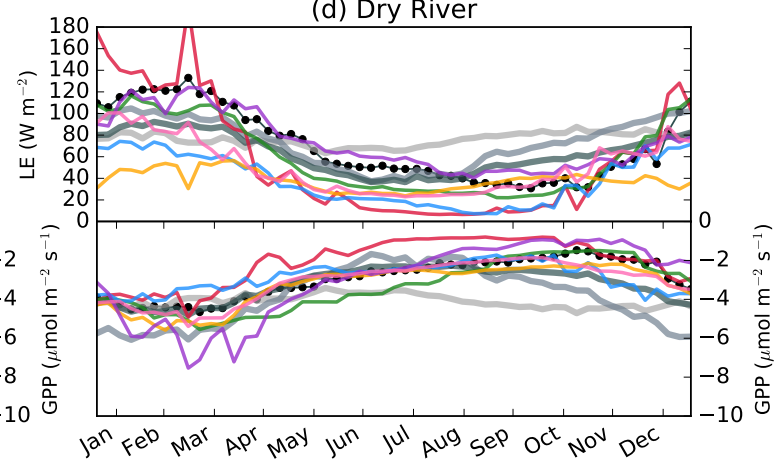

(e) Sturt Plains

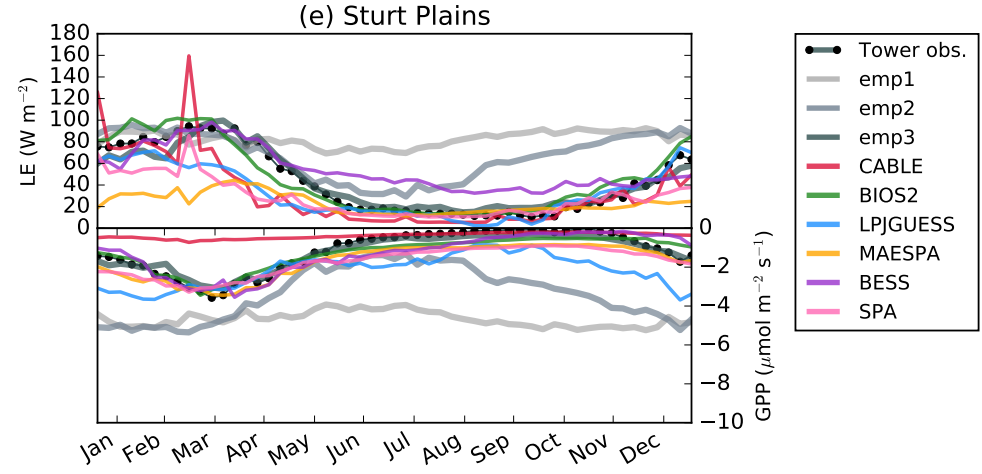

Figure 2. Time series of daily mean latent heat (LE) flux and gross primary productivity (GPP) depicting an average year for each of the five savanna sites using a smoothed, 7-day moving average. The sites are ordered from wettest to driest: (a) Howard Springs, (b) Adelaide River, (c) Daly River, (d) Dry River, and (e) Sturt Plains. The joined black dots are the tower flux time series, while the grey lines are the performance benchmarks (emp1, emp2, emp3). Predictions of LE and GPP for each of the six terrestrial biosphere models are given by a spectrum of colours described in the legend.

Finally, we assess ecosystem model performance in terms of a ranking system, following the PLUMBER methodology of Best et al. (2015). The performance of each individual ecosystem model in predicting both LE and GPP at each site was determined using four statistical metrics that describe the mean and variability of a model compared to the observations. These metrics included the correlation coefficient $(r)$, standard deviation, normalised mean error, and mean bias error (see Table A1 in Appendix A). Similarly, the same metrics were determined for each of the three benchmarks at each savanna site. Each TBM was then ranked against the benchmarks (independently of the other models) for each of the metrics listed above, where the ranking is between 1 and 4 ( 1 model +3 benchmarks) and the best performing model for a given metric is ranked as 1 . An average ranking is then determined across all metrics for each TBM and all benchmarks to give a final ranking of performance for each savanna site. The ranks denote the number of metrics being met by the models and are not a measure of the smallest absolute error. In determining the average ranks, the metrics were evaluated at the daily timescale, as this was the lowest temporal resolution common amongst the six TBMs. Additionally, days 
where either driver or flux had been gap-filled were removed. Here we use the term performance to relate to how well the TBMs compare to the benchmarks as expressed by the ranks.

\section{Results}

\subsection{Model predictions}

Figure 2 shows the daily time course of LE and GPP from the flux tower, models, and benchmarks at each of the five savanna sites. Models, benchmarks, and observations are represented as a smoothed time series (7-day running mean) and have been aggregated into an ensemble year to express the typical seasonality of savanna water and carbon exchange. Visually, the TBMs showed varying levels of performance across the rainfall gradient. None of the models showed a clear consistency in simulating either flux, and each responded differently to the meteorological drivers across sites. Additionally, some of the models, such as CABLE and LPJGUESS, showed difficulty in simulating the seasonality of the fluxes across the transect, particularly GPP. Differences among model-simulated LE and GPP were larger in the wet season than the dry season. However, modelled LE and GPP appeared to co-vary quite strongly; overall both fluxes were underestimated across sites by most models. Simulations by SPA and MAESPA were the exception to this, broadly capturing tower GPP despite consistently underestimating LE across sites.

Figure 3 shows the probability density functions (PDFs) for the wet (November-April) and dry season (MayOctober) fluxes at each site. Tower and model PDFs were determined by binning each flux into the respective seasons and using kernel density estimation (Bashtannyk and Hyndman, 2001) to determine smoothed distributions. The shape and mean position of the distributions indicate the ability of the models to capture the extremes (day-to-day variability) and the seasonality of the fluxes respectively, highlighting possible predictive biases (i.e. the over- or underestimation of the tower fluxes). Across the NATT, the PDFs for the tower fluxes tended to shift to low values and became narrower as annual rainfall declined, and this was most prominent in the dry season. A change in the spread and mean position of the flux tower PDFs demonstrate the strong seasonality of water and carbon exchange at all sites. The PDFs of the model simulations did not replicate this trend, having high densities and being mostly stationary across sites. Regarding savanna water use, the distributions of the BIOS2 and SPA models were similar to those of the flux towers. The BESS model also showed a similar distribution of LE, despite the fact that it did not simulate soil-water extraction. The LPJGUESS model, which had the shallowest simulated tree rooting depth, displayed PDFs of high density that were biased towards low LE $\left(20-40 \mathrm{~W} \mathrm{~m}^{-2}\right)$ across all sites and seasons. The MAESPA model showed a similar behaviour, despite this model having a much deeper simulated rooting depth and a root-water extraction scheme that is equivalent to the SPA model. The distributions for the CABLE and BIOS2 models were largely disparate despite these models being functionally equivalent. Notably, CABLE wet season LE was more broadly distributed $\left(5-200 \mathrm{~W} \mathrm{~m}^{-2}\right)$ than the flux towers and other models at all sites, while dry season LE was narrower. In relation to savanna carbon uptake, all models showed wet and dry season PDFs of high density that became more closely aligned with the flux tower distributions as the sites became drier. The behaviour of the modelled GPP distributions were otherwise similar to those of the modelled LE distributions. The differences among TBM and flux tower PDFs indicated possible issues in simulated processes that are active during the wet season.

The benchmarks set low to high levels of expected TBM performance across the NATT. Additionally, they also demonstrated the level of model complexity that is required to simulate water and carbon exchange at these sites. The simplest of the benchmarks, represented as a linear regression of the fluxes against $R_{\mathrm{S}}$ (emp1), which was capable of predicting the magnitude and daily time course of the tower fluxes (data not shown), but there was not enough information in $R_{\mathrm{S}}$ to capture the seasonality or the distribution of the fluxes expressed by the tower data. The intermediate benchmark that included additional meteorological information on $T_{\mathrm{a}}$ and VPD (emp2) demonstrated an improved capability in capturing the flux distributions but could not replicate the full seasonality of the fluxes across the NATT. It was only by including additional phenological information (LAI) together with site meteorology $\left(R_{\mathrm{S}}, T_{\mathrm{a}}\right.$, and VPD) that the seasonality and distribution of the fluxes could be captured, as demonstrated by the most complex benchmark (emp3). This indicated that in order for the TBMs to achieve the best possible performance at simulating water and carbon exchange along the NATT, the correct implementation and utilisation of phenological information by the models was required. All TBMs used in this study utilised this breadth of information, but only some of the models were capable of meeting the expected level of performance set by the emp 3 benchmark, and then only for specific sites and seasons.

\subsection{Residual analysis}

An analysis of the model residuals was conducted to show how model structure affects the prediction of savanna fluxes across the rainfall gradient. To do this we examined the standardised model residuals from each TBM, determined by expressing the residual error in terms of its standard deviation. Figure 4 shows the residual time series for model-predicted LE and GPP at each savanna site and provides an effective way of examining how a model responds to progressive changes in the environment through the expression of model bias and error (Medlyn et al., 2005). 

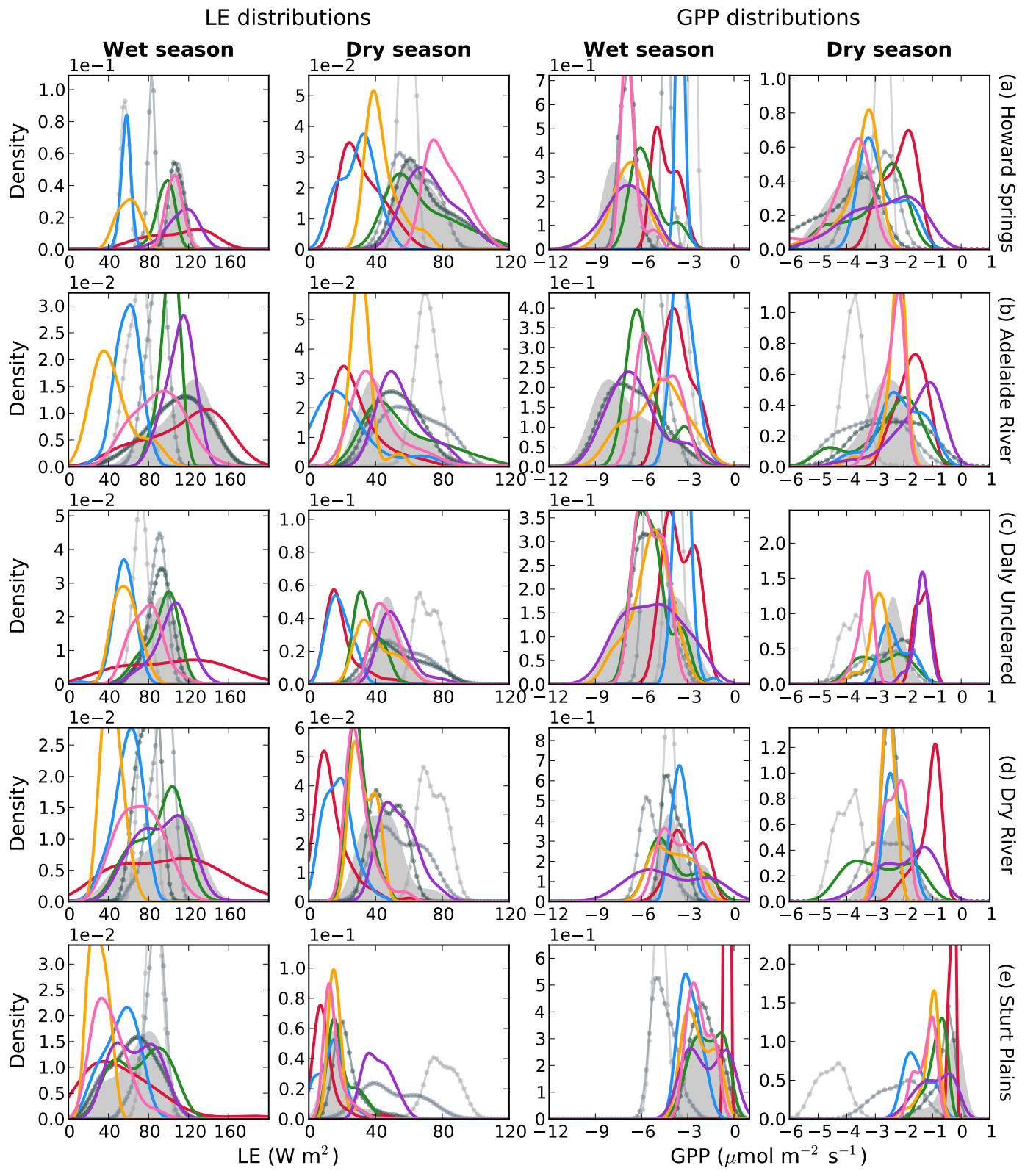

\begin{tabular}{|c|c|c|c|c|c|c|c|c|c|}
\hline$\square$ & $\begin{array}{l}\text { Tower obs. } \\
\text { empl }\end{array}$ & - & $\begin{array}{l}\text { emp2 } \\
\text { emp3 }\end{array}$ & - & $\begin{array}{l}\text { CABLE } \\
\text { BIOS2 }\end{array}$ & - & $\begin{array}{l}\text { LPJGUESS } \\
\text { MAESPA }\end{array}$ & 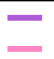 & $\begin{array}{l}\text { BESS } \\
\text { SPA }\end{array}$ \\
\hline
\end{tabular}

Figure 3. Probability densities (expressed in scientific notation) of daily mean latent heat (LE) flux and gross primary productivity (GPP) at each of the five savanna sites, where the distributions for each flux are partitioned into wet and dry seasons. The order of the sites are from wettest to driest; (a) Howard Springs, (b) Adelaide River, (c) Daly River, (d) Dry River, and (e) Sturt Plains. The grey region is the tower flux, while the dotted lines are the empirical benchmarks. Predicted LE and GPP probability densities from each of the six process-based models are given by a spectrum of colours described in the legend.

The model residuals demonstrated that there was significant bias and heteroscedasticity in predicted LE and GPP in almost all cases. The residual time series showed that model error was largest in the wet season but declined with the transition into the dry season. Additionally, the models underestimated LE and GPP more significantly during the wet sea- son . A possible explanation for this behaviour is that during the wet season, multiple land-surface components: the soil surface, the understorey grasses, and the tree canopy (i.e. three sources for potential error) contribute to the bulk fluxes, while during the dry season only the tree canopy contributes (i.e. one source for potential error). It is likely that 
(a) CABLE

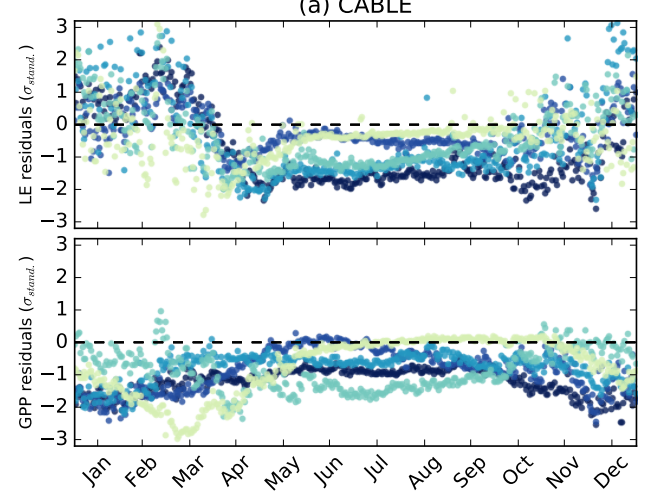

(c) LPJGUESS

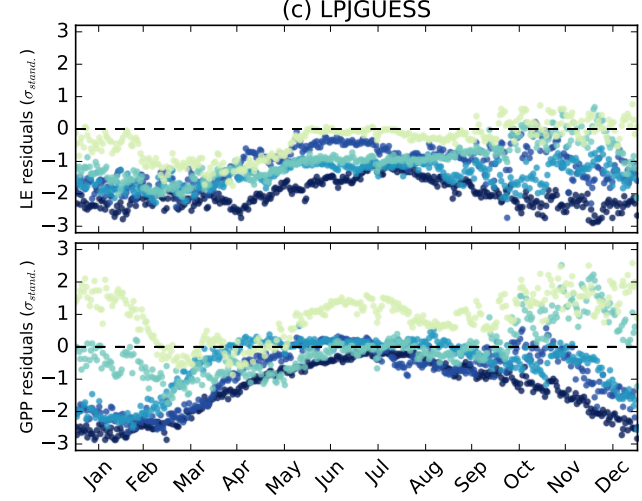

(e) BESS

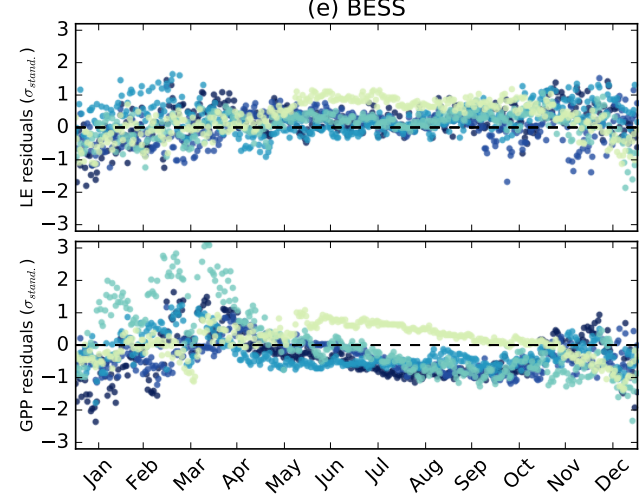

(b) BIOS2

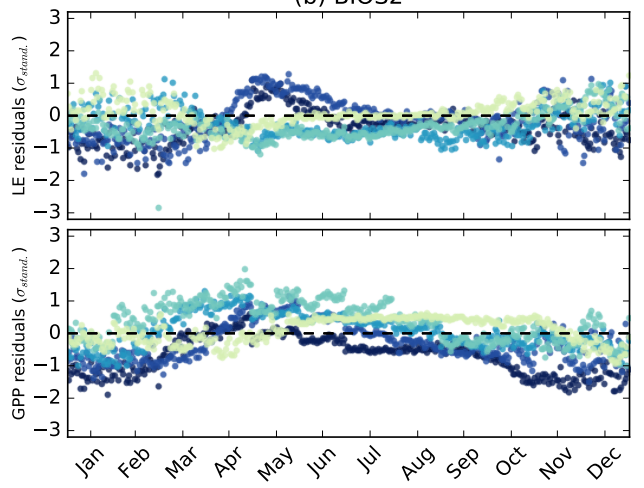

(d) MAESPA

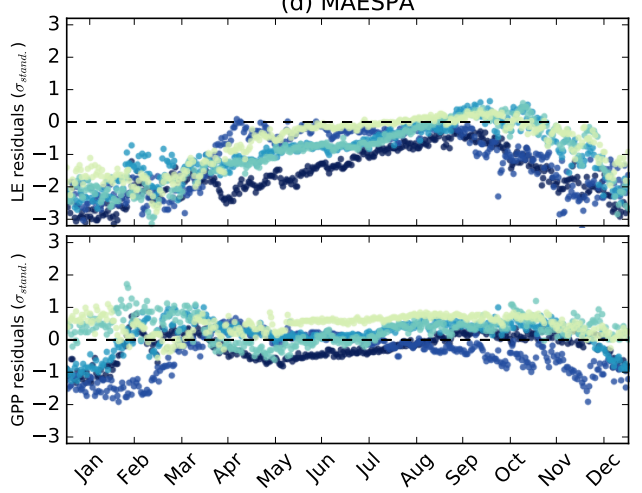

(f) SPA

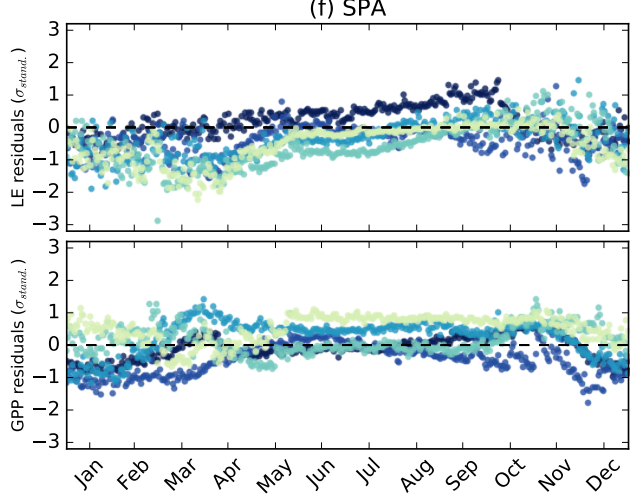

Howard Springs

- Adelaide River

Daly Uncleared

Dry River

Sturt Plains

Figure 4. Standardised model residuals for latent energy (LE) and gross primary productivity (GPP) expressed in units of standard deviations (SD) [(modelled flux - observed flux)/SD(observed flux)]. Residuals are presented for each model: (a) CABLE, (b) BIOS2, (c) LPJGUESS, (d) MAESPA, (d) BESS, and (e) SPA, where each flux site is represented by a blue-green-yellow gradient. For both fluxes, the residuals are plotted against time (ensemble average year) and against the flux prediction (bias).

the reduction in residual error between wet and dry seasons was a result of the declining influence of the grasses and the soil surface to ecosystem land-surface exchange during the latter period (via senescence and low surface soil moisture respectively). The bias towards the underestimation of wet season fluxes was more pronounced at the mesic sites (Howard Springs, Adelaide River), despite some models simulating relatively deep root profiles (e.g. BIOS2, MAESPA).
Differences in how the TBMs simulated root-water extraction also had no effect on reducing this bias (e.g. MAESPA, SPA). Given that soil-water was not a limiting factor at the mesic sites during this period, deep root profiles offered limited advantage towards model performance. Nonetheless, the simulated tree root zone appeared to be an important factor for all sites during the dry season, with shallow root depths (LPJGUESS: $2 \mathrm{~m}$ ) and/or inadequate root-water up- 


\section{(a) Annual performance}

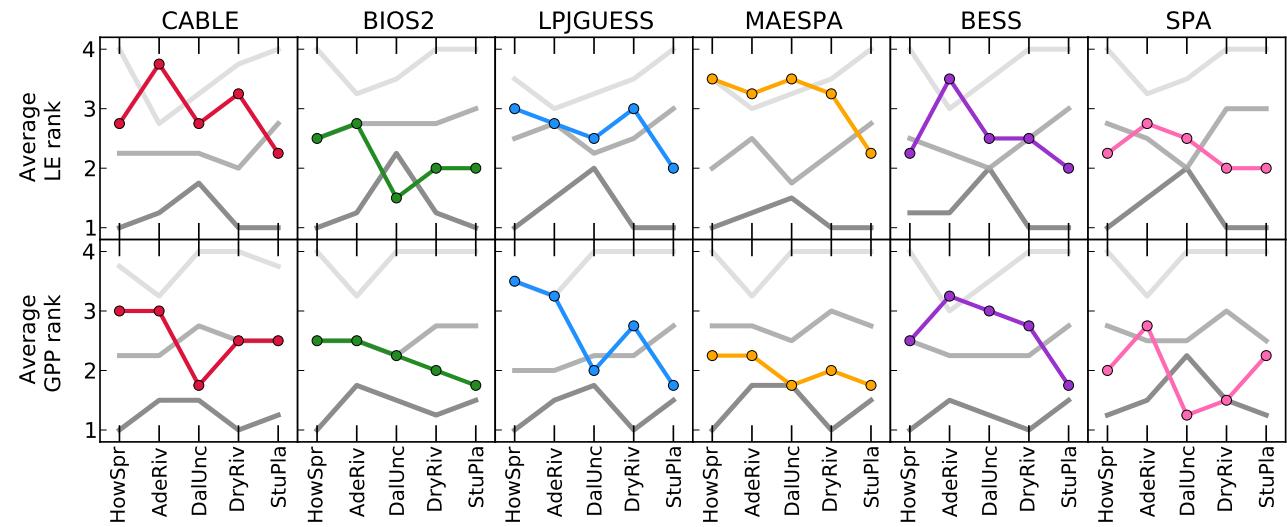

(b) Wet season performance

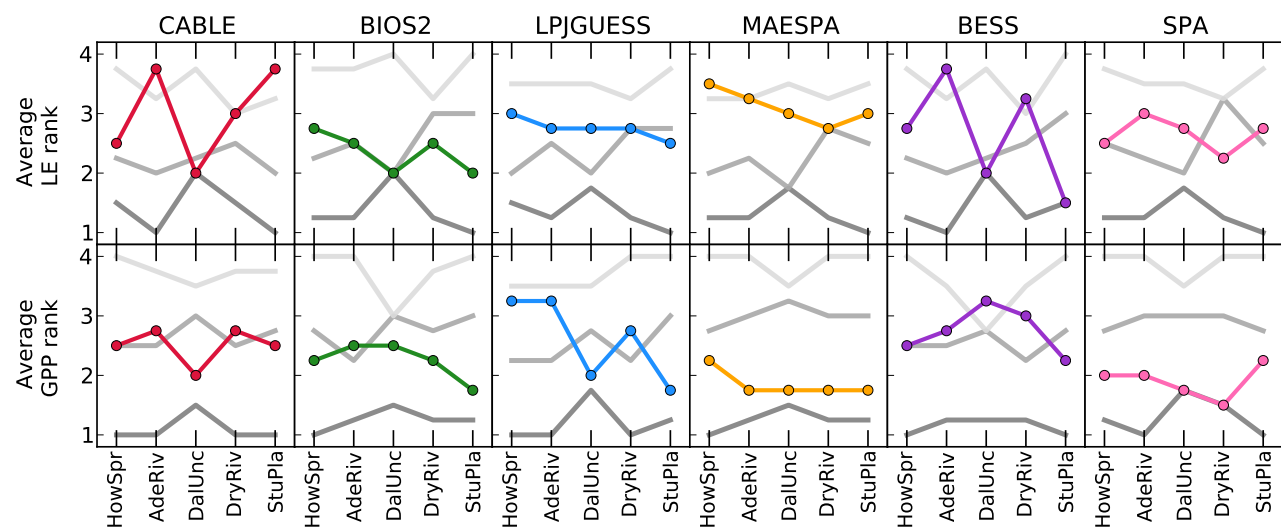

(c) Dry season performance

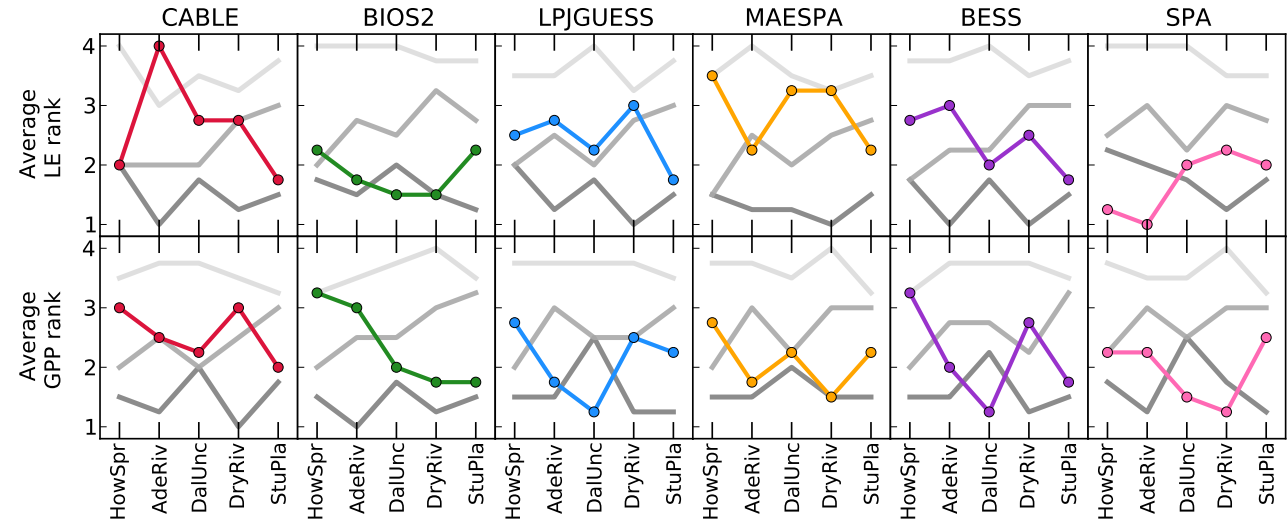

$\because$ emp3 emp2 $=$ emp1 $\bullet$ model

Figure 5. Average rank plot showing the performance of the terrestrial biosphere models for all sites across the North Australian Tropical Transect (NATT) ordered in terms of annual rainfall as follows: Howard Springs (HowSpr), Adelaide River (AdrRiv), Daly Uncleared (DalUnc), Dry River (DryRiv), and Sturt Plains (StuPla). Models are individually ranked against the benchmarks on the order of 1 to 4 ( 1 model +3 benchmarks) and express the amount of metrics the models are meeting listed in Table S1. The rankings are determined individually for latent energy (LE) and gross primary productivity (GPP). The coloured lines represent each of the six models in the study, while the grey lines represent the empirical benchmarks. The average ranking for each model was determined for (a) a complete year, (b) the wet season, and (c) the dry season. 
take schemes (CABLE: concentrated in the upper soil profile) the likely cause for underestimation during this period. However, as the sites became drier (e.g. Sturt Plains) a shallow root profile was suitable to give flux estimates of a reasonably low error. Despite model error reducing with the increase in ecosystem water limitation that occurs in both space (down the NATT) and time (wet to dry season), there are still patterns of model bias that may be unrelated to simulated soil-water dynamics. This is particularly obvious during the wet-to-dry transition periods (e.g. BIOS2, SPA) when the $\mathrm{C}_{4}$ grass understorey senesces, indicating possible problems with the how the models translate information on phenology.

\subsection{Model performance}

Figure 5 shows a comparison of individual TBM performance ordered by site from wettest (Howard Springs) to driest (Sturt Plains) and in terms of their annual, wet, and dry season predictions for each flux. Despite differences in model complexity (Table 1), the TBMs showed a similar performance across sites and seasons. For almost all sites, the TBMs outperformed the emp1 benchmark for annual flux predictions (Fig. 5a). However, there were some exceptions to this, and good performance in one flux did not necessarily result in good performance in the other. For example, MAESPA was unable to beat the emp1 benchmark for LE at sites where MAP $>1000 \mathrm{~mm}$ but performed better than the emp2 benchmark for GPP. In general, there was a slight pattern of increased model performance as annual rainfall declined, though with a degree of site-to-site variability in the rankings for some of the TBMs.

In order to examine how seasonal changes affect model performance, we additionally determined the metrics and rankings for the wet and dry season periods (Fig. 5b-c). Seasonal differences were immediately obvious. Model performance for wet season LE and GPP was low to moderate, and the majority of the TBMs showed a performance that ranged between the emp 1 and emp 2 benchmarks. In contrast, there were noticeable improvements to dry season model performance amongst the TBMs. For dry season LE, half the models (BIOS2, BESS, and SPA) were able to consistently outperform the emp2 benchmark and come close to meeting the same number of metrics as the emp 3 benchmark particularly at the drier sites. In comparison, predicted dry season GPP saw a larger enhancement in model performance, with TBMs more frequently outperforming the emp2 benchmark and even some outperforming the emp3 benchmark (LPJGUESS, BESS, and SPA at the Daly Uncleared site). The exception to all this was the CABLE model, which showed surprisingly little loss or gain in performance despite the season. The results give an indication that, as a whole, input information was better utilised by each TBM at drier sites and in the dry season, suggesting that there are problems in wet season processes.

\section{Discussion}

The NATT, which covers a marked rainfall gradient, presents a natural "living laboratory" with which a model's ability to simulate fluxes in savanna ecosystems may be assessed. Our results have highlighted that there is a clear failure of the models to adequately perform at predicting wet season dynamics, as compared to the dry season, and suggests that modelled processes relating to the $\mathrm{C}_{4}$ grass understorey are insufficient. This highlights a key weakness of this group of TBMs, which likely extends to other models outside of this study. The inability of these TBMs to capture wet season dynamics is highlighted by the benchmarking, where the performance for many of the models was at best equivalent to that of a multi-linear regression against $R_{\mathrm{S}}, T_{\mathrm{a}}$, and VPD (emp2) and in some cases no better than a linear regression against $R_{\mathrm{S}}$ (emp1). Given that this subset of TBMs are sophisticated process-based models that represent our best understanding of land surface-atmospheric exchange processes, we would expect them to perform as well as a neural network prediction (emp3). Consequently there is an evident underutilisation of the driving information (i.e. a failure to describe the underlying relationships in the data) impeding the performance of these models when predicting savanna fluxes. However, there were instances where some of the TBMs were able to reach similar levels of performance with the emp3 benchmark, which strongly suggests that each of these models is capable of replicating savanna dynamics under certain conditions (e.g. during the dry season).

Our results suggest that errors among models are likely to be systematic, rather than related to calibration of existing parameters. For example, BIOS2 had previously optimised model parameters for Australian vegetation (see Haverd et al., 2013) but was still unable to out-perform the emp3 benchmark in most cases, although it performed better than an un-calibrated CABLE, to which it is functionally similar. Similarly, MAESPA and SPA, which used considerable site characteristic information to parameterise their simulations, did not significantly outperform un-calibrated models (e.g. CABLE). Additionally, despite these models using the same leaf, root, and soil parameterisations, both SPA and MAESPA displayed markedly different performances in predicting LE. Consequently, improving how models represent key processes that drive savanna dynamics is critical to improving model performance across this ecosystem.

There is certainly enough information in the time-varying model inputs to be able to adequately simulate wet and dry season dynamics, as is evidenced by the benchmarks. We therefore consider the implications of our results, present possible reasons below for why this group of TBMs is failing to capture water and carbon exchange along the NATT, and make suggestions as to how this could be improved. 


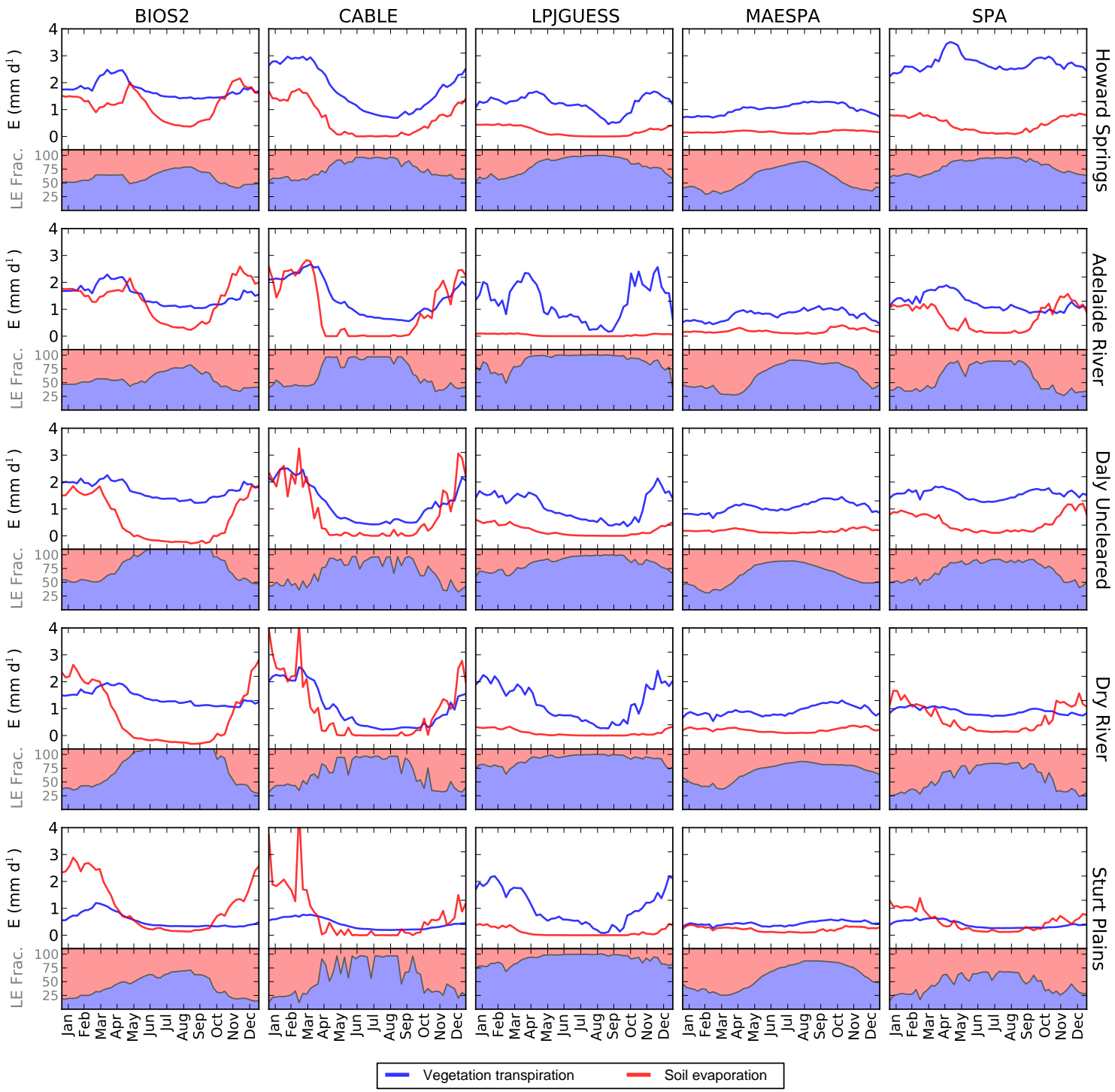

Figure 6. Average year outputs of vegetation transpiration (grass + trees) and soil evaporation, as well as their percentage contributions to total latent energy (LE) for each of the six terrestrial biosphere models at each of the five savanna sites.

\subsection{Water access and tree rooting depth}

During the late dry season surface soil moisture in the sandy soils declines to less than $3 \%$ volumetric water content, with an equivalent matric potential of 3 to $4 \mathrm{MPa}$ (Prior et al., 1997). During this seasonal phase, the grass understorey becomes inactive and LE can be considered as equivalent to tree transpiration, such that it is the only active component during this period (O'Grady et al., 1999). Using this equivalence, one can infer the relative effect that rooting depth has on LE during this period. Previous studies have shown that for these savanna sites along the NATT, tree transpiration is maintained throughout the dry season by deep root systems that access deep soil-water stores, which in turn are recharged over the wet season (Eamus et al., 2000; Hutley et al., 2001; Kelley et al., 2007; O'Grady et al., 1999). In order for models to perform well they will need to set adequate rooting depths and distributions, along with root-water uptake process, to enable a model response to such seasonal variation. Examining performance across the models, we can infer this to be a key deficiency. As expected, TBMs that prescribed shallow rooting depths (e.g. LPJGUESS) did not simulate this process well and underestimated dry season LE at three of the five savanna sites by up to 30 to $40 \%$. The two sites at Adelaide River and Sturt Plains were an exception to this with the TBMs displaying a low residual error, which is likely to be a consequence of heavier textured soils and trees at these sites having shallow root profiles. At Adelaide River shallow root profiles are a consequence of shallow, heavier textured soils; however, dry season transpiration 
is sustained due to the presence of saturated yellow hydrosol soils. Sturt Plains is a grassland (the end member of the savanna continuum) where $\mathrm{C}_{4}$ grasses dominate and no trees are present such that transpiration is close to zero in the dry season. The few small shrubs that are established have shallow root profiles that have adapted to isolated rainfall events driven by convective storms (Eamus et al., 2001; Hutley et al., 2001, 2011). Consequently, the TBMs would be expected to perform better at these sites, as water and carbon exchange will be modulated by the soil-water status of the sub-surface soil layers. For the other sites, models which assumed a root depth $>5 \mathrm{~m}$ (BIOS2, SPA, and MAESPA) showed the most consistent performance in predicting dry season LE, and we suggest that for seasonally water-limited ecosystems, such as savanna, deeper soil-water access is critical. Our results highlight the need for data with which to derive more mechanistic approaches to setting rooting depth, such as that of Schymanski et al. (2009).

Interestingly, a low residual error for LE in the dry season did not translate as good performance in the overall model ranking. This suggests that other processes along the soilvegetation-atmosphere continuum need to be considered to improve simulated woody transpiration. Such processes may include root-water uptake (distribution of roots and how water is extracted), and the effect of water stress and increased atmospheric demand at the leaf level (adjustment of stomatal conductance due to changes in leaf water potential). More detailed model experiments that examine how each TBM simulates these processes would help identify how they can be improved.

An exception to the above is the BESS model, which forgoes simulating belowground processes of soil hydrology and root-water uptake entirely. Rather, this model assumes that the effects of soil-moisture stress on water and carbon exchange is expressed through changes in LAI (and by extension $V_{\text {cmax }}$ ), which acts as a proxy for changes in soil moisture content (Ryu et al., 2011). The fact that BESS performed moderately well along the NATT, coupled with the fact that tree transpiration continues through the dry season, suggests that there may be enough active green material for remote sensing proxies of water stress to generally work rather well for savanna ecosystems. It is notable that BESS overestimated both GPP and ET in dry season at the driest site, Sturt Plains (Fig. 2e), implying that greenness detected by satellite remote sensing might not capture carbon and water dynamics well in such a dry site.

\subsection{Savanna wet season dynamics}

The relative performance of the TBMs at predicting LE was much poorer in the wet season compared to the dry season. The reason for this difference is that wet season LE is the sum of woody and herbaceous transpiration $\left(E_{\mathrm{veg}}\right)$ as well as soil and wet-surface evaporation $\left(E_{\text {soil }}\right)$; in contrast, dry season LE is predominantly woody transpiration as described previ- ously. During the wet season, up to $75 \%$ of total LE arises from understorey herbaceous transpiration and soil evaporation (Eamus et al., 2001; Hutley et al., 2000; Moore et al., 2016) and of this fraction the $\mathrm{C}_{4}$ grasses contribute a significant daily amount (Hutley et al., 2000). In the absence of observations of understory LE it can be difficult to determine whether grass transpiration is being simulated correctly. However, separating out the components of wet season LE into soil and vegetation can help identify which of these components are causes for error.

Separating the outputs of simulated $E_{\text {veg }}$ and $E_{\text {soil }}$ from each TBM (excluding BESS which did not determine these as outputs during the study) shows that simulated wet season $E_{\text {veg }}$ was particularly low for a lot of the models, despite high LAI and non-limiting soil-water conditions (Fig. 6). A previous study at Howard Springs by Hutley et al. (2000) observed that, during the wet season, the grass understorey could transpire $\sim 2.8 \mathrm{~mm} \mathrm{~d}^{-1}$, while the tree canopy transpired only $0.9 \mathrm{~mm} \mathrm{~d}^{-1}\left(E_{\mathrm{veg}}=3.7 \mathrm{~mm} \mathrm{~d}^{-1}\right)$. Of the six TBMs at Howard Springs, only CABLE and SPA were able to predict an $E_{\text {veg }}$ close to this level, while the other models predicted values closer to tree transpiration (i.e. an underestimate). This pattern is similar for other NATT sites, where predicted wet season $E_{\mathrm{veg}}$ remained low and was dominated by $E_{\text {soil }}$ at the southern end of the NATT. An underestimation of wet season LE could be due to underestimated $E_{\text {soil }}$ in some of the models. Conversely, CABLE and BIOS2 predicted a higher $E_{\text {soil }}$ than the other models, and this could be a reason for their higher LE performance during the wet season. Although $E_{\text {soil }}$ has been reported to reach as high as $2.8 \mathrm{~mm} \mathrm{~d}^{-1}$ at Howard Springs (Hutley et al., 2000), predicted $E_{\text {soil }}$ by these models may still be overestimated, given that vegetation cover during this period is at a seasonal peak (limiting energy available at the soil surface) and transpiration is only limited by available energy, not water (Hutley et al., 2000; Ma et al., 2013; Schymanski et al., 2009; Whitley et al., 2011). Given the limited data for $E_{\text {soil }}$ along the NATT, it is difficult to determine how large $E_{\text {soil }}$ should be. However, the ratios displayed by the TBMs appear to be reasonable, with vegetation acting as the predominant pathway for surface water flux.

Grass transpiration is thus clearly being underrepresented by most of the TBMs, and reasons for this could be due to multiple factors. The evolution of $\mathrm{C}_{4}$ grasses to fix carbon under low light, low $\mathrm{CO}_{2}$ concentrations, and high temperatures has resulted in a gas-exchange process that is highly water-use efficient (von Caemmerer and Furbank, 1999). Consequently, this life form is abundant in tropical, waterlimited ecosystems, where it can contribute to more than $50 \%$ of total LAI (2.0 to 2.5), particularly at high rainfall sites (Sea et al., 2011). The annual strategy of the $\mathrm{C}_{4}$ grasses at these sites is to indiscriminately expend all available resources to maximise productivity during the monsoon period, for growth and to increase leaf area. This therefore allows grass transpiration to exceed tree transpiration during 
the peak wet season as evergreen trees will be more conservative in their water use, allowing them to remain active in the dry season (Eamus et al., 2001; Hutley et al., 2000; Scholes and Archer, 1997). Following this logic, our results suggest that the TBMs are either (i) incorrectly ascribing leaf area to the understorey (i.e. the $\mathrm{C}_{4}$ fractional cover is too low), (ii) incorrectly describing the $\mathrm{C}_{4}$ leaf-gas exchange physiology, (iii) incorrectly describing the understory micro climatic environment $\left(R_{\mathrm{S}}, T_{\mathrm{a}}, \mathrm{VPD}\right)$, or (iv) a combination of these causes. Furthermore, it should be noted that the TBMs used in this study are not truly modelling grasses, but approximating them. Grasses are effectively simulated as "stemless" trees, and the distinction between the two life forms is reliant on different parameter sets (e.g. $V_{\text {cmax }}$, height) and slight modifications of the same process (e.g. rate of assimilation, respiration). While our results and the tower data do not allow us to directly determine how $\mathrm{C}_{4}$ grasses may be misrepresented in these TBMs, they clearly indicate that future development and evaluation should be focused on these issues. Eddy covariance studies of understorey savanna vegetation as conducted by Moore et al. (2016) will be critical to this process.

\subsection{Savanna phenology}

The results from this study have shown that to simulate savanna fluxes, TBMs must be able to simulate the dynamics of savanna phenology, expressed by LAI. This was highlighted by the empirical benchmarks, where the results showed that while $R_{\mathrm{S}}, T_{\mathrm{a}}$, and VPD were important drivers, LAI was required to capture the seasonality and magnitude of the fluxes to achieve good performance. LAI integrates the observed structural changes of the savanna as annual rainfall declines with reduced woody stem density, driving water and carbon exchange as a result (Kanniah et al., 2010; Ma et al., 2013; Sea et al., 2011). When LAI is prescribed in a model, it is important that leaf area is partitioned correctly between the trees and grass layers to describe their respective phenology. This partitioning is important, as the $\mathrm{C}_{4}$ grass understorey explains most of the seasonal variation in LAI and is a consequence of an annual phenology that exhibits rapid growth at the onset of the wet season and senescence at the onset of the dry (R. J. Williams et al., 1996). By contrast, the evergreen eucalypt canopy shows modest reductions in canopy leaf area during the dry season, especially as mean annual rainfall declines (Bowman and Prior, 2005; Kelley et al., 2007). The strong seasonal dynamics of the grasses result in large changes in LAI, with levels varying between 0.7 and 2.5 at high rainfall sites (Sea et al., 2011). The phenological strategy of the $\mathrm{C}_{4}$ grasses also changes with rainfall interannual variability, with the onset of the greening period becoming progressively delayed as sites become drier, to become eventually rain-pulse driven as the monsoonal influence weakens (Ma et al., 2013).
With the exception of LPJGUESS, all models prescribed LAI as an input driver. Prescribing LAI can be problematic depending on the timescale and how it is partitioned between trees and grass layers. At large time steps (months) it will fail to capture the rapidly changing dynamics of vegetation during the transition periods, and this is particularly true for the onset of the wet season (September-November) especially at drier sites that are subject to larger interannual rainfall variability (Hutley et al., 2011). Additionally, as the sites become drier the tree: grass ratio will become smaller and this dynamic can be difficult to predict, although methods do exist (see Donohue et al., 2009). From the results, we infer that TBMs that prescribe LAI and allow for a dynamic representation of tree and grass ratios are better able to capture the changing dynamics of the savanna system. This is a possible explanation for the better performance of the BIOS2, MAESPA and SPA models in simulating GPP as these models dynamically partition leaf area between trees and grasses at the sub-monthly timescale, rather than using a bulk value. However, models that prescribe LAI have limited capability in simulating the land-surface response of savannas to changing climate, as tree and grass cover is the outcome of the environmental forcing (particularly rainfall variability and disturbance) and not a driver of the system (Sankaran et al., 2005). DGVMs that consider dynamic vegetation and use a prognostic LAI can simulate the feedback between the climate and the relative cover of trees and grasses, which shapes the savanna continuum. This feedback allows the simulated savanna structure to potentially shift to alternate states (e.g. grassland or forest) in response to changes in annual rainfall and fire severity (Scheiter and Higgins, 2007, 2009). While LPJGUESS was the only TBM to use a prognostic LAI in our study, it achieved only moderate performance, and this may be due to how carbon is allocated from the pool on an annual time step, such that it is not as dynamic as it could be. However, its capability to simulate the feedback between climate and LAI is critical for simulating how savanna dynamics may change from year to year. There may also be issues with how phenology is simulated, particularly as it is determined from empirical formulations, which are (i) not specifically developed for savanna environments and (ii) calculated before the growing season begins. Such formulations are therefore not mechanistic and do not respond to actual season dynamics (e.g. limiting soil water), but they are empirically determined (Richardson et al., 2013).

\section{Conclusions}

This study set out to assess how well a set of functionally different, state-of-the-art TBMs perform at predicting the bulk exchanges of carbon and water over savanna land surfaces. Our model inter-comparison has identified key weaknesses in the assumptions of biosphere-atmosphere processes, which do not hold for savanna environments. Our benchmarking 
has identified low model performance by TBMs is likely a result of incorrect assumptions related to (i) deep soil-water access, (ii) a systematic underestimation of the contribution of the grass understorey in the wet season, and (iii) the use of static phenology to represent dynamic vegetation. Our results showed that these assumptions, as they currently exist in TBMs, are not wholly supported by "observations" of savanna water and carbon exchange and need to be addressed if more reliable projections are to be made on how savannas respond to environmental change. Despite this, our benchmarking has shown that all TBMs could potentially operate well for savanna ecosystems provided that the above issues are developed. We suggest that further work investigate how particular processes in the models may be affecting overall predicted water and carbon fluxes and may include testing variable rooting depths, alternate root-water uptake schemes and how these might affect leaf-level outputs (e.g. stomatal conductance, leaf water potential) among TBMs, and different phenology schemes. The issues highlighted here also have scope beyond savanna environments, and are relevant to other water-limited ecosystems. The results from this study provide a foundation for improving how savanna ecosystem dynamics are simulated.

\section{Data availability}

Half-hourly eddy-covariance data sets pertaining to each of the savanna sites used in this study are available from http: //data.ozflux.org.au (Isaac and van Gorsel, 2016). Soil descriptions for each savanna site are derived from the Digital Atlas of Australian Soils available at www.asris.csiro.au (Isbell, 2016). 


\section{Appendix A}

Table A1. Definition of common metrics used to determine ranks against the empirical benchmarks. The terms $M$ and $O$ stand for model and observations respectively, while $n$ denotes the length of the data, and $i$ is the datum.

\begin{tabular}{ll}
\hline Statistical metric & Definition \\
\hline Correlation coefficient $(r)$ & $\sqrt{\left.\left(n \sum_{i=1}^{n} O_{i}^{2}-\left(\sum_{i=1}^{n} O_{i}\right)^{2}\right)\left(n O_{i} M_{i}\right)-\sum_{i=1}^{n} O_{i} \sum_{i=1}^{n} M_{i}^{2}-\left(\sum_{i=1}^{n} M_{i}\right)^{2}\right)}$ \\
\hline Standard deviation (SD) & $\mid 1-\frac{\sqrt{\frac{1}{n-1} \sum_{i=1}^{n}\left(M_{i}-\bar{M}\right)^{2}} \mid}{\sqrt{\frac{1}{n-1} \sum_{i=1}^{n}\left(O_{i}-\bar{O}\right)^{2}} \mid}$ \\
\hline Normalised mean error (NME) & $\frac{\sum_{i=1}^{n}\left|M_{i}-O_{i}\right|}{\sum_{i=1}^{n}\left|\bar{O}-O_{i}\right|}$ \\
\hline Normalised mean bias (MBE) & $\frac{1}{n} \sum_{i=1}^{n}\left(M_{i}-O_{i}\right)$ \\
\hline
\end{tabular}




\section{The Supplement related to this article is available online at doi:10.5194/bg-13-3245-2016-supplement.}

Acknowledgements. This study was conducted as part of the "Australian Savanna Landscapes: Past, Present and Future" project funded by the Australian Research Council (DP130101566). The support, collection, and utilisation of data was provided by the OzFlux network (www.ozflux.org.au) and Terrestrial Ecosystem Research Network (TERN; www.tern.org.au) and funded by the ARC (DP0344744, DP0772981, and DP130101566). PALS was partly funded by the TERN ecosystem Modelling and Scaling infrAStructure (eMAST) facility under the National Collaborative Research Infrastructure Strategy (NCRIS) 2013-2014 budget initiative of the Australian Government Department of Industry. Rhys Whitley was supported through the ARC Discovery Grant (DP130101566). Jason Beringer is funded under an ARC FT (FT110100602). Vanessa Haverd's contribution was supported by the Australian Climate Change Science Program. We acknowledge the support of the Australian Research Council Centre of Excellence for Climate System Science (CE110001028).

Edited by: N. Kljun

\section{References}

Abramowitz, G.: Towards a public, standardized, diagnostic benchmarking system for land surface models, Geosci. Model Dev., 5, 819-827, doi:10.5194/gmd-5-819-2012, 2012.

Abramowitz, G., Leuning, R., Clark, M., and Pitman, A.: Evaluating the Performance of Land Surface Models, J. Climate, 21, 54685481, doi:10.1175/2008JCLI2378.1, 2008.

Ball, J. T., Woodrow, I. E., and Berry, J. A.: A model predicting stomatal conductance and its contribution to the control of photosynthesis under different environmental conditions, in: Progress in Photosynthesis Research, Martinus-Nijhoff Publishers, Dordrecht, the Netherlands, 221-224, 1987.

Bashtannyk, D. M. and Hyndman, R. J.: Bandwidth selection for kernel conditional density estimation, Comput. Stat. Data An., 36, 279-298, doi:10.1016/S0167-9473(00)00046-3, 2001.

Beringer, J., Hutley, L. B., Tapper, N. J., and Cernusak, L. A.: Savanna fires and their impact on net ecosystem productivity in North Australia, Glob. Change Biol., 13, 990-1004, doi:10.1111/j.1365-2486.2007.01334.x, 2007.

Beringer, J., Hutley, L. B., Hacker, J. M., Neininger, B., and Paw, U. K. T.: Patterns and processes of carbon, water and energy cycles across northern Australian landscapes: From point to region, Agr. Forest Meteorol., 151, 1409-1416, doi:10.1016/j.agrformet.2011.05.003, 2011.

Beringer, J., Hutley, L. B., Abramson, D., Arndt, S. K., Briggs, P., Bristow, M., Canadell, J. G., Cernusak, L. A., Eamus, D., Evans, B. J., Fest, B., Goergen, K., Grover, S. P., Hacker, J., Haverd, V., Kanniah, K., Livesley, S. J., Lynch, A., Maier, S., Moore, C., Raupach, M., Russell-Smith, J., Scheiter, S., Tapper, N. J., and Uotila, P.: Fire in Australian Savannas: from leaf to landscape, Glob. Change Biol., 21, 62-81, doi:10.1111/gcb.12686, 2015.
Best, M. J., Abramowitz, G., Johnson, H. R., Pitman, A. J., Balsamo, G., Boone, A., Cuntz, M., Decharme, B., Dirmeyer, P. A., Dong, J., Ek, M., Guo, Z., Haverd, V., van den Hurk, B. J., Nearing, G. S., Pak, B., Peters-Lidard, C., Santanello Jr, J. A., Stevens, L., and Vuichard, N.: The plumbing of land surface models: benchmarking model performance, J. Hydrometeorol., 16, 1425-1442, 2015.

Bond, W. J.: What Limits Trees in C4 Grasslands and Savannas?, Annu. Rev. Ecol. Evol. Syst., 39, 641-659, doi:10.1146/annurev.ecolsys.39.110707.173411, 2008.

Bowman, D. M. J. S. and Prior, L. D.: Why do evergreen trees dominate the Australian seasonal tropics?, Aust. J. Bot., 53, 379-399, doi:10.1071/BT05022, 2005.

Cernusak, L. A., Hutley, L. B., Beringer, J., Holtum, J. A. M., and Turner, B. L.: Photosynthetic physiology of eucalypts along a sub-continental rainfall gradient in northern Australia, Agr. Forest. Meteorol., 151, 1462-1470, doi:10.1016/j.agrformet.2011.01.006, 2011.

Chapin, F. S., Woodwell, G. M., Randerson, J. T., Rastetter, E. B., Lovett, G. M., Baldocchi, D. D., Clark, D. A., Harmon, M. E., Schimel, D. S., Valentini, R., Wirth, C., Aber, J. D., Cole, J. J., Goulden, M. L., Harden, J. W., Heimann, M., Howarth, R. W., Matson, P. A., McGuire, A. D., Melillo, J. M., Mooney, H. A., Neff, J. C., Houghton, R. A., Pace, M. L., Ryan, M. G., Running, S. W., Sala, O. E., Schlesinger, W. H., and Schulze, E. D.: Reconciling carbon-cycle concepts, terminology, and methods, Ecosystems, 9, 1041-1050, doi:10.1007/s10021-005-0105-7, 2006.

Chen, X., Hutley, L. B., and Eamus, D.: Carbon balance of a tropical savanna of northern Australia, Oecologia, 137, 405-16, doi:10.1007/s00442-003-1358-5, 2003.

Collatz, G. J., Ball, J. T., Grivet, C., and Berry, J. A.: Physiological and environmental regulation of stomatal conductance, photosynthesis and transpiration: a model that includes a laminar boundary layer, Agr. Forest. Meteorol., 54, 107-136, 1991.

Collatz, G. J., Ribas-Carbo, M., and Berry, J. A.: Coupled photosynthesis-stomatal conductance model for leaves of $\mathrm{C} 4$ plants, Funct. Plant Biol., 19, 519-538, 1992.

De Kauwe, M. G., Zhou, S.-X., Medlyn, B. E., Pitman, A. J., Wang, Y.-P., Duursma, R. A., and Prentice, I. C.: Do land surface models need to include differential plant species responses to drought? Examining model predictions across a mesic-xeric gradient in Europe, Biogeosciences, 12, 7503-7518, doi:10.5194/bg-127503-2015, 2015.

Donohue, R. J., Mc Vicar, T. R., and Roderick, M. L.: Climaterelated trends in Australian vegetation cover as inferred from satellite observations, 1981-2006, Glob. Change Biol., 15, 10251039, doi:10.1111/j.1365-2486.2008.01746.x, 2009.

Duursma, R. A. and Medlyn, B. E.: MAESPA: a model to study interactions between water limitation, environmental drivers and vegetation function at tree and stand levels, with an example application to [CO2] $\times$ drought interactions, Geosci. Model Dev., 5, 919-940, doi:10.5194/gmd-5-919-2012, 2012.

Eamus, D., O'Grady, A. P. O., and Hutley, L. B.: Dry season conditions determine wet season water use in the wet-tropical savannas of northern Australia, Tree Physiol., 20, 1219-1226, 2000.

Eamus, D., Hutley, L. B., and O'Grady, A. P. O.: Daily and seasonal patterns of carbon and water fluxes above a north Australian savanna, Tree Physiol., 21, 977-88, 2001. 
Eamus, D., Chen, X., Kelley, G., and Hutley, L. B.: Root biomass and root fractal analyses of an open Eucalyptus forest in a savanna of north Australia, Aust. J. Bot., 50, 31-41, 2002.

Eamus, D., Cleverly, J., Boulain, N., Grant, N., Faux, R., and Villalobos-Vega, R.: Carbon and water fluxes in an arid-zone Acacia savanna woodland: An analyses of seasonal patterns and responses to rainfall events, Agr. Forest. Meteorol., 182-183, 225-238, doi:10.1016/j.agrformet.2013.04.020, 2013.

Farquhar, G. D., von Caemmerer, S., and Berry, J. A.: A Biochemical Model of Photosynthetic $\mathrm{CO}_{2}$ Assimilation in Leaves of $\mathrm{C} 3$ species, Planta, 149, 78-90, 1980.

Grace, J., Jose, J. S., Meir, P., Miranda, H. S., and Montes, R. A.: Productivity and carbon fluxes of tropical savannas, J. Biogeogr., 33, 387-400, doi:10.1111/j.1365-2699.2005.01448.x, 2006.

Haverd, V., Raupach, M. R., Briggs, P. R., Canadell, J. G., Isaac, P., Pickett-Heaps, C., Roxburgh, S. H., van Gorsel, E., Viscarra Rossel, R. A., and Wang, Z.: Multiple observation types reduce uncertainty in Australia's terrestrial carbon and water cycles, Biogeosciences, 10, 2011-2040, doi:10.5194/bg-10-2011-2013, 2013

Haverd, V., Smith, B., Raupach, M., Briggs, P., Nieradzik, L., Beringer, J., Hutley, L., Trudinger, C. M., and Cleverly, J.: Coupling carbon allocation with leaf and root phenology predicts tree-grass partitioning along a savanna rainfall gradient, Biogeosciences, 13, 761-779, doi:10.5194/bg-13-761-2016, 2016.

Haxeltine, A. and Prentice, I. C.: A general model for the lightuse efficiency of primary production, Funct. Ecol., 10, 551-561, doi:10.2307/2390165, 1996.

Higgins, S. I. and Scheiter, S.: Atmospheric $\mathrm{CO}_{2}$ forces abrupt vegetation shifts locally, but not globally, Nature, 488, 209-212, doi:10.1038/nature11238, 2012.

Hsu, K.: Self-organizing linear output map (SOLO): An artificial neural network suitable for hydrologic modeling and analysis, Water Resour. Res., 38, 1-17, doi:10.1029/2001WR000795, 2002.

Huntingford, C. and Monteith, J. L.: The behaviour of a mixedlayer model of the convective boundary layer coupled to a big leaf model of surface energy partitioning, Bound.-Lay. Meteorol., 88, 87-101, doi:10.1023/A:1001110819090, 1998.

Hutchinson, M. F. and Xu, T.: ANUCLIM v6.1, Fenner School of Environment and Society, Australian National University, Canberra, ACT, 2010.

Hutley, L. B., O'Grady, A. P. O., and Eamus, D.: Evapotranspiration from Eucalypt open-forest savanna of Northern Australia, Funct. Ecol., 14, 183-194, 2000.

Hutley, L. B., Grady, A. P. O., and Eamus, D.: Monsoonal influences on evapotranspiration of savanna vegetation of northern Australia, Oecologia, 126, 434-443, doi:10.1007/s004420000539, 2001.

Hutley, L. B., Beringer, J., Isaac, P. R., Hacker, J. M., and Cernusak, L. A.: A sub-continental scale living laboratory: Spatial patterns of savanna vegetation over a rainfall gradient in northern Australia, Agr. Forest. Meteorol., 151, 1417-1428, doi:10.1016/j.agrformet.2011.03.002, 2011.

Isaac, P. and van Gorsel, E.: OzFlux: Australian and New Zealand Flux Research and Monitoring, available at: http://data.ozflux. org.au, last access: 1 June 2016.

Isbell, R.: The Australian Soil Classification, Revised Edn., CSIRO Publishing, Collingwood, Victoria, 2002.
Isbell, R. F.: Digital Atlas of Australian Soils, available at: http: //www.asris.csiro.au/downloads/Atlas/soilAtlas2M.zip, last access: 1 June 2016.

Kanniah, K. D., Beringer, J., and Hutley, L. B.: The comparative role of key environmental factors in determining savanna productivity and carbon fluxes: A review, with special reference to northern Australia, Prog. Phys. Geogr., 34, 459-490, doi:10.1177/0309133310364933, 2010.

Kelley, G., O'Grady, A. P., Hutley, L. B., and Eamus, D.: A comparison of tree water use in two contiguous vegetation communities of the seasonally dry tropics of northern Australia: The importance of site water budget to tree hydraulics, Aust. J. Bot., 55, 700-708, doi:10.1071/BT07021, 2007.

Koch, G. W., Vitousek, P. M., Steffen, W. L., and Walker, B. H.: Terrestrial transects for global change research, Vegetation, 121, 53-65, doi:10.1007/BF00044672, 1995.

Kowalczyk, E. A., Wang, Y. P., and Law, R. M.: The CSIRO Atmosphere Biosphere Land Exchange (CABLE) model for use in climate models and as an offline model, Aspendale, Victoria, 2006.

Lehmann, C. E. R., Prior, L. D., and Bowman, D. M. J. S.: Decadal dynamics of tree cover in an Australian tropical savanna, Austral Ecology, 34, 601-612, doi:10.1111/j.1442-9993.2009.01964.x, 2009.

Lehmann, C. E. R., Anderson, T. M., Sankaran, M., Higgins, S. I., Archibald, S., Hoffmann, W. A., Hanan, N. P., Williams, R. J., Fensham, R. J., Felfili, J., Hutley, L. B., Ratnam, J., San Jose, J., Montes, R., Franklin, D., Russell-Smith, J., Ryan, C. M., Durigan, G., Hiernaux, P., Haidar, R., Bowman, D. M. J. S., and Bond, W. J.: Savanna vegetation-fire-climate relationships differ among continents, Science, 343, 548-552, doi:10.1126/science.1247355, 2014.

Leuning, R.: A critical appraisal of a combined stomatalphotosynthesis model for C3 plants, Plant Cell Environ., 18, 339-355, 1995.

Li, L., Wang, Y. P., Yu, Q., Pak, B., Eamus, D., Yan, J., Van Gorsel, E., and Baker, I. T.: Improving the responses of the Australian community land surface model (CABLE) to seasonal drought, J. Geophys. Res.-Biogeo., 117, 1-16, doi:10.1029/2012JG002038, 2012.

Ma, X., Huete, A., Yu, Q., Coupe, N. R., Davies, K., Broich, M., Ratana, P., Beringer, J., Hutley, L. B., Cleverly, J., Boulain, N., and Eamus, D.: Spatial patterns and temporal dynamics in savanna vegetation phenology across the North Australian Tropical Transect, Remote Sens. Environ., 139, 97-115, doi:10.1016/j.rse.2013.07.030, 2013.

McKenzie, N. N., Jacquier, D., Isbell, R., and Brown, K.: Australian soils and landscapes?: an illustrated compendium, CSIRO Publishing, Collingwood, Victoria, 2004.

Medlyn, B. E., Robinson, A. P., Clement, R., and McMurtrie, R. E.: On the validation of models of forest $\mathrm{CO}_{2}$ exchange using eddy covariance data: some perils and pitfalls, Tree Physiol., 25, 839-857, 2005.

Medlyn, B. E., Duursma, R. A., Eamus, D., Ellsworth, D. S., Prentice, I. C., Barton, C. V. M., Crous, K. Y., De Angelis, P., Freeman, M., and Wingate, L.: Reconciling the optimal and empirical approaches to modelling stomatal conductance, Glob. Change Biol., 17, 2134-2144, doi:10.1111/j.1365-2486.2010.02375.x, 2011. 
Moore, C. E., Beringer, J., Evans, B., Hutley, L. B., McHugh, I., and Tapper, N. J.: The contribution of trees and grasses to productivity of an Australian tropical savanna, Biogeosciences, 13, 2387-2403, doi:10.5194/bg-13-2387-2016, 2016.

O'Grady, A. P. O., Eamus, D., and Hutley, L. B.: Transpiration increases during the dry season: patterns of tree water use in eucalypt open-forests of northern Australia, Tree Physiol., 19, 591597, 1999.

Parton, W. J., Anderson, D. W., Cole, C. V., and Stewart, J. W. B.: Simulation of soil organic matter formation and mineralization in semiarid agroecosystems, in: Nutrient Cycling In Agricultural Ecosystems, 23, 533-550, 1983.

Pitman, A. J.: The evolution of and revolution in, land surface schemes designed for climate models, Int. J. Climatol., 23, 479510, doi:10.1002/joc.893, 2003.

Prior, L. D., Eamus, D., and Duff, G. A.: Seasonal Trends in Carbon Assimilation, Stomatal Conductance, Pre-dawn Leaf Water Potential and Growth in Terminalia ferdinandiana, a Deciduous Tree of Northern Australian Savannas, Aust. J. Bot., 45, 53-69, 1997.

Richardson, A. D., Keenan, T. F., Migliavacca, M., Ryu, Y., Sonnentag, O., and Toomey, M.: Climate change, phenology, and phenological control of vegetation feedbacks to the climate system, Agr. Forest. Meteorol., 169, 156-173, doi:10.1016/j.agrformet.2012.09.012, 2013.

Russell-Smith, J. and Edwards, A. C.: Seasonality and fire severity in savanna landscapes of monsoonal northern Australia, Int. J. Wildland Fire, 15, 541-550, doi:10.1071/WF05111, 2006.

Ryu, Y., Baldocchi, D. D., Kobayashi, H., van Ingen, C., Li, J., Black, T. A., Beringer, J., van Gorsel, E., Knohl, A., Law, B. E., and Roupsard, O.: Integration of MODIS land and atmosphere products with a coupled-process model to estimate gross primary productivity and evapotranspiration from $1 \mathrm{~km}$ to global scales, Global Biogeochem. Cy., 25, GB4017, doi:10.1029/2011GB004053, 2011.

Ryu, Y., Baldocchi, D. D., Black, T. A., Detto, M., Law, B. E., Leuning, R., Miyata, A., Reichstein, M., Vargas, R., Ammann, C., Beringer, J., Flanagan, L. B., Gu, L., Hutley, L. B., Kim, J., McCaughey, H., Moors, E. J., Rambal, S., and Vesala, T.: On the temporal upscaling of evapotranspiration from instantaneous remote sensing measurements to 8day mean daily-sums, Agr. Forest. Meteorol., 152, 212-222, doi:10.1016/j.agrformet.2011.09.010, 2012.

Sankaran, M., Hanan, N. P., Scholes, R. J., Ratnam, J., Augustine, D. J., Cade, B. S., Gignoux, J., Higgins, S. I., Le Roux, X., Ludwig, F., Ardo, J., Banyikwa, F., Bronn, A., Bucini, G., Caylor, K. K., Coughenour, M. B., Diouf, A., Ekaya, W., Feral, C. J., February, E. C., Frost, P. G. H., Hiernaux, P., Hrabar, H., Metzger, K. L., Prins, H. H. T., Ringrose, S., Sea, W., Tews, J., Worden, J., and Zambatis, N.: Determinants of woody cover in African savannas, Nature, 438, 846-849, doi:10.1038/nature04070, 2005.

Scheiter, S. and Higgins, S. I.: Partitioning of root and shoot competition and the stability of savannas, Am. Nat., 170, 587-601, doi:10.1086/521317, 2007.

Scheiter, S. and Higgins, S. I.: Impacts of climate change on the vegetation of Africa: an adaptive dynamic vegetation modelling approach, Glob. Change Biol., 15, 2224-2246, doi:10.1111/j.13652486.2008.01838.x, 2009.
Scheiter, S., Higgins, S. I., Beringer, J., and Hutley, L. B.: Climate change and long-term fire management impacts on Australian savannas, New Phytol., 205, 1211-1226, doi:10.1111/nph.13130, 2015.

Scholes, R. J. and Archer, S. R.: Tree-grass interactions in savannas, Annu. Rev. Ecol. Syst., 28, 517-544, doi:10.1146/annurev.ecolsys.28.1.517, 1997.

Schymanski, S. J., Roderick, M. L., Sivapalan, M., Hutley, L. B., and Beringer, J.: A test of the optimality approach to modelling canopy properties and $\mathrm{CO}_{2}$ uptake by natural vegetation, Plant. Cell Environ., 30, 1586-98, doi:10.1111/j.13653040.2007.01728.x, 2007.

Schymanski, S. J., Sivapalan, M., Roderick, M. L., Beringer, J., and Hutley, L. B.: An optimality-based model of the coupled soil moisture and root dynamics, Hydrol. Earth Syst. Sci., 12, 913932, doi:10.5194/hess-12-913-2008, 2008.

Schymanski, S. J., Sivapalan, M., Roderick, M. L., Hutley, L. B., and Beringer, J.: An optimality-based model of the dynamic feedbacks between natural vegetation and the water balance, Water Resour. Res., 45, W01412, doi:10.1029/2008WR006841, 2009.

Sea, W. B., Choler, P., Beringer, J., Weinmann, R. A., Hutley, L. B., and Leuning, R.: Documenting improvement in leaf area index estimates from MODIS using hemispherical photos for Australian savannas, Agr. Forest. Meteorol., 151, 1453-1461, doi:10.1016/j.agrformet.2010.12.006, 2011.

Simioni, G., Roux, X. Le, Gignoux, J., and Sinoquet, H.: Treegrass: a 3-D, process-based model for simulating plant interactions in tree-grass ecosystems, Ecol. Modell., 131, 47-63, 2000.

Simioni, G., Gignoux, J., and Le Roux, X.: Tree layer spatial structure can affect savanna production and water budget: Results of a 3-D model, Ecology, 84, 1879-1894, doi:10.1890/00129658(2003)084[1879:TLSSCA]2.0.CO;2, 2003.

Sitch, S., Smith, B., Prentice, I. C., Arneth, A., Bondeau, A., Cramer, W., Kaplan, J., Levis, S., Lucht, W., Sykes, M., Thonicke, K., and Venevski, S.: Evaluation of ecosystem dynamics, plant geography and terrestrial carbon cycling in the LPJ dynamic vegetation model, Glob. Change Biol., 9, 161-185, 2003.

Smith, B., Prentice, I. C., and Sykes, M. T.: Representation of vegetation dynamics in the modelling of terrestrial ecosystems: Comparing two contrasting approaches within European climate space, Global Ecol. Biogeogr., 10, 621-637, doi:10.1046/j.1466822X.2001.t01-1-00256.x, 2001.

Still, C. J., Berry, J. A., Collatz, G. J., and DeFries, R. S.: Global distribution of $\mathrm{C} 3$ and $\mathrm{C} 4$ vegetation: Carbon cycle implications, Global Biogeochem. Cy., 17, 6-1-6-14, doi:10.1029/2001GB001807, 2003.

Tuzet, A., Perrier, A., and Leuning, R.: A coupled model of stomatal conductance, photosynthesis, Plant Cell Environ., 26, 1097$1117,2003$.

van der Werf, G. R., Randerson, J. T., Giglio, L., Gobron, N., and Dolman, A. J.: Climate controls on the variability of fires in the tropics and subtropics, Global Biogeochem. Cy., 22, 1-13, doi:10.1029/2007GB003122, 2008.

von Caemmerer, S. and Furbank, R. T.: Modeling C4 Photosynthesis, in: C4 Plant Biology, edited by: Sage, R. F. and Monson, R. K., 173-211, Academic Press, Toronto, 1999.

Wang, Y. P., Kowalczyk, E., Leuning, R., Abramowitz, G., Raupach, M. R., Pak, B., Van Gorsel, E., and Luhar, A.: Diag- 
nosing errors in a land surface model (CABLE) in the time and frequency domains, J. Geophys. Res.-Biogeo., 116, 1-18, doi:10.1029/2010JG001385, 2011.

Whitley, R. J., Macinnis-Ng, C. M. O., Hutley, L. B., Beringer, J., Zeppel, M., Williams, M., Taylor, D., and Eamus, D.: Is productivity of mesic savannas light limited or water limited? Results of a simulation study, Glob. Change Biol., 17, 3130-3149, doi:10.1111/j.1365-2486.2011.02425.x, 2011.

Williams, M., Rastetter, E. B., Fernandes, D. N., Goulden, M. L., Wofsy, S. C., Shaver, G. R., Melillo, J. M., Munger, J. W., Fan, S.-M., and Nadelhoffer, K. J.: Modelling the soil-plantatmosphere continuum in a Quercus Acer stand at Harvard Forest: the regulation of stomatal conductance by light, nitrogen and soil/plant hydraulic properties, Plant Cell Environ., 19, 911-927, 1996.
Williams, R. J., Duff, G. A., Bowman, D. M. J. S., and Cook, G. D.: Variation in the composition and structure of tropical savannas as a function of rainfall and soil texture along a large-scale climatic gradient in the Northern Territory, Australia, J. Biogeogr., 23, 747-756, doi:10.1111/j.1365-2699.1996.tb00036.x, 1996. 